\title{
Jurnal Ilmu Kehutanan
}

\author{
Journal of Forest Science
}

https://jurnal.ugm.ac.id/jikfkt

\section{Variasi Karakter Pembungaan Antar Varian dan Ras Lahan Cendana Sepanjang Gradien Geografis di Gunung Sewu}

The Flowering Characters Variation Among Floral Variants and Landraces Along

Geographical Gradients in Gunung Sewu

Yeni W N Ratnaningrum*, Sapto Indrioko, Eny Faridah, \& Atus Syahbudin

Departemen Silvikultur, Fakultas Kehutanan, Universitas Gadjah Mada, Jl. Agro No. 1, Bulaksumur, Sleman, 55281

*Email : yeni.wnr@ugm.ac.id

\section{HASIL PENELITIAN}

Riwayat naskah:

Naskah masuk (received): 12 Agustus 2016

Diterima (accepted): 9 Maret 2017

\section{KEYWORDS}

flowering

sandalwood

floral variant

land-race

Gunung Sewu

\section{ABSTRACT}

Sandalwood was origin to the south-eastern islands of Indonesia, but is recently occured as new land-races in Gunung Sewu, Java island. All of land-races consisted of three floral variants (MK, refers to "merah kecil"; $M B$, "merah besar"; and KB, "kuning besar", respectively). This research aimed to determine flowering of these variants among three of land-races which were representing geographical zone in Gunung Sewu: Nglanggeran, Blebera, and Petir. Observation on phenology, sexual organs maturity, floral structure, and display was conducted in 2015. Floral structures varied among variants. $M B$ and KB dominated by red and maroon colors, possessed bigger perigonium, longer sexual organs but with shorter longevity, and similar/lower position of stylus to stamens. MK dominated by yellow to orange colors, smaller, similar/higher position of stylus, and longer longevity. Floral display varied among land-races but were similar among variants. Petir, with biggest population size, produced the most abundant flowers and flowering trees at all variants. Sandalwood flowered twice a year in all of land-races and variants, however, the onset and duration varied. KB flowered earliest while MB was the latest. MK possessed longest flowering period. Flowering varied among land-races due to the altitude, soils, and climatic differences. Lower altitude, drier, and warmer sites flowered earlier and shorter. Mass abortion and sequential replacement, resulting in the alteration on flowering frequency, occured due to the extreme temperature increment. Conservation strategy should be arranged based on genetic differentiation, flowering differences, and crossing abilities among variants. Differences of landscapes, which may contribute to the differences of environmental conditions and flowering processes, should also be considered. 
KATA KUNCI

pembungaan

cendana

varian bunga

ras lahan

Gunung Sewu

\section{INTISARI}

Cendana merupakan spesies asli Indonesia bagian timur, yang menjadi ras lahan di Gunung Sewu. Sembilan ras lahan di Gunung Sewu, seluruhnya tersusun atas tiga varian yang berbeda struktur dan warna bunganya (MK, merah kecil; MB, merah besar; dan KB, kuning besar). Penelitian ini bertujuan untuk menganalisis karakter pembungaan ketiga varian cendana di Gunung Sewu pada periode pembungaan tahun 2015; di tiga ras lahan yang mewakili tiap zona yaitu Nglanggeran (Zona Utara), Bleberan (Zona Tengah), dan Petir (Zona Selatan). Observasi meliputi fenologi, kemasakan organ reproduksi, display, dan struktur pembungaan. Struktur pembungaan dan longevity organ reproduksi berbeda antar varian. MB dan KB didominasi warna merah dan marun, perigonium lebih besar, organ reproduksi lebih panjang, posisi putik sejajar/lebih rendah dari benang sari, dan longevity lebih singkat. MK didominasi kuning hingga oranye, lebih kecil, posisi putik sejajar/lebih tinggi, dan longevity lebih lama. Display pembungaan berbeda antar ras lahan, namun tidak berbeda antar varian. Petir, dengan ukuran populasi terbesar, memproduksi paling banyak pohon berbunga dan total bunga untuk seluruh varian. Ras lahan dan varian berbunga dua kali setahun, namun dengan inisiasi dan durasi yang berbeda. KB berbunga lebih awal di seluruh ras lahan, sedangkan MB paling akhir. MK memiliki durasi pembungaan terpanjang. Perbedaan antar ras lahan lebih dipengaruhi oleh faktor lingkungan seperti ketinggian, jenis tanah, dan iklim. Ras lahan yang lebih rendah, kering, dan panas berbunga lebih awal dan singkat. Peningkatan temperatur dan turunnya status air tanah menyebabkan keguguran massal yang diikuti sequential replacement, mengakibatkan perubahan frekuensi pembungaan. Strategi konservasi cendana di Gunung Sewu perlu dirancang berbasis keragaman genetik, sinkroni pembungaan, dan kompatibilitas antar varian, dengan tetap mempertimbangkan keberagaman tempat tumbuhnya.

(C) Jurnal Ilmu Kehutanan-All rights reserved

\section{Pendahuluan}

Pembungaan merupakan salah satu fokus dalam konservasi genetik (White et al. 2007) dikarenakan perannya dalam menentukan pola perkawinan dan struktur genetik populasi (Arroyo et al. 2006; Barrett et al. 2006). Komponen pembungaan terdiri dari fenologi, struktur, dan display perbungaan (Owens et al. 1991). Struktur dan display perbungaan mempengaruhi keberhasilan penyerbukan (Herlihy \& Eckert 2005; Arroyo et al. 2006) dan reproduksi (Wolf et al. 2001; Collin \& Shykoff 2003; Weber \& Kolb 2013; Agullo et al. 2015). Fenologi pembungaan, yang meliputi inisiasi, frekuensi, dan durasi pembungaan (Owens et al. 1991), merupakan mekanisme alami untuk beradaptasi secara ekologis maupun fisiologis terhadap kondisi lingkungan (Barrett et al. 2006; Richardson et al. 2013). Variasi fenologi pembungaan berkontribusi pada struktur populasi (Tsaliki \& Diekmann 2011; Richardson et al. 2013), perilaku agen penyerbuk (Herlihy \& Eckert 2005; Arroyo et al. 2006), aliran gen (Alizoti et al. 2010; Yang et al. 2013; Park et al. 2014), serta karakter reproduksi (Collin \& Shykoff 2003; Alizoti et al. 2010; Weber \& Kolb 2013; Agullo et al. 2015).

Santalum album Linn. (Santalaceae), selanjutnya disebut cendana, merupakan salah satu kayu mewah termahal di dunia dikarenakan harga kayu dan minyaknya yang sangat tinggi (Angadi et al. 2003; Rao 
et al. 2007). Bukti molekuler menunjukkan bahwa Indonesia bagian Tenggara merupakan center of origin seluruh cendana yang ada di dunia saat ini. Bahkan, cendana di India dan Australia juga diduga merupakan hasil introduksi dari Timor ribuan tahun yang lalu (Angadi et al. 1993; Harbaugh \& Baldwin 2007; Rao et al. 2007). Beberapa dekade sebelumnya, Australia, India, dan Indonesia merupakan eksportir cendana terbesar (Angadi et al. 1993; Rao et al. 2007). Namun, fragmentasi dan hilangnya habitat cendana menjadikannya dikategorikan sebagai Vulnerable dalam IUCN Red List of Endangered Species. Dalam sepuluh tahun terakhir, sangat dimungkinkan kategori ini telah berubah menjadi Critically Endangered atau bahkan Extinct in The Wild (IUCN 2009).

Upaya re-introduksi cendana ke habitat alaminya di Kepulauan Indonesia bagian tenggara telah dilakukan selama lima tahun terakhir, namun rendahnya kualitas material genetik mengakibatkan sangat rendahnya viabilitas biji dan persen hidup (Indrioko \& Ratnaningrum 2015). Pada bulan Oktober 2015, Pemerintah Indonesia menyatakan gagalnya program re-introduksi cendana di Timor dan NTT (Anonim 2015), dan rendahnya viabilitas biji dianggap sebagai penyebab utamanya (Balai Penelitian Kehutanan Kupang, komunikasi pribadi). Rendahnya kualitas biji ini sangat dimungkinkan merupakan akibat dari kegagalan proses reproduksi (reproductive failure); fenomena yang juga teramati pada Santalum lanceolatum di Australia (Warburton et al. 2000), $S$. insulare di Kepulauan Pasifik (Lhuillier et al. 2006), $S$. album di India semenanjung (Rao et al. 2007) dan India Selatan (Dani et al. 2011), S. spicatum di Australia Barat (Byrne et al. 2003) dan S. austrocaledonicum di New Caledonia (Bottin et al. 2007).

Cendana untuk keperluan re-introduksi di Indonesia, salah satunya, diambil dari ras lahan di kawasan Gunung Sewu (Balai Penelitian Kehutanan Kupang, komunikasi pribadi), yang pada tahun 2015 telah ditetapkan oleh UNESCO sebagai Global
Geopark Network. Beberapa ras lahan tersebar sepanjang Zona Utara, Tengah, dan Selatan dari GeoArea Gunungkidul. Di samping itu, terdapat beberapa areal konservasi ex situ di Zona Tengah (Dinas Kehutanan DIY 2015). Spesimen herbarium tertua cendana di Yogyakarta, tertanggal 12 Juli 1853, dikoleksi dari Kecamatan Imogiri (koleksi LIPI), sedangkan spesimen lainnya dikoleksi pada tahun 196o dari Kecamatan Nglipar (koleksi Museum Biologi UGM). Potensi Gunung Sewu sebagai sumber materi genetik untuk re-introduksi sangat besar, dengan mempertimbangkan bahwa beberapa ras lahan, terutama yang berbasis genetik luas, memiliki variasi genetik dan kemampuan reproduksi tinggi (Indrioko \& Ratnaningrum 2015).

Gunung Sewu memiliki sejarah formasi geografis yang beragam, yang menjadikannya memiliki kondisi lanskap yang beragam pula (Simanjuntak 2002; Haryono \& Suratman 2010). Sehubungan dengan hal itu, dimungkinkan ras lahan cendana yang ada di dalamnya juga sangat bervariasi, baik dalam hal struktur populasi, struktur genetik maupun karakter reproduksinya. Terdapat sembilan ras lahan cendana di GeoArea Gunungkidul, yang bervariasi dalam aspek ketinggian tempat, tipe iklim, jenis, dan kedalaman tanahnya (Dinas Kehutanan DIY 2015). Seluruh ras lahan juga tersusun atas tiga varian cendana dengan struktur bunga yang berbeda (Ratnaningrum \& Indrioko 2016; Indrioko \& Ratnaningrum 2016). Perbedaan struktur populasi (Byrne et al. 2003; Bottin et al. 2007; Dani et al. 2011) dan struktur reproduksi (Rughkla et al. 2006; Warburton et al. 2000; Rao et al. 2007; Herlihy \& Eckert 2005; Barrett et al. 2006; Tamla et al. 2012) dapat berakibat pada berbedanya sistem perkawinan dan proses reproduksi. Hal serupa terjadi pada Santalum album di India (Rughkla et al. 2006), $S$. album, S. lanceolatum dan S. spicatum di Australia Barat (Tamla et al. 2012) dan S. lanceolatum di Victoria (Warburton et al. 2000), yang mengalami kegagalan pembuahan dikarenakan perbedaan struktur organ reproduksi pada beberapa varian cendana. 
Walaupun sangat krusial untuk dilakukan, ternyata masih sangat sedikit penelitian yang menghubungkan pengaruh karakter pembungaan dan struktur populasi terhadap kemampuan reproduksi cendana. Sebagian besar penelitian tersebut dilakukan di India Selatan (Sindhu-Vereendra \& AnanthaPadmanabha 1993; Suma \& Balasundaran 2003; Rao et al. 2007), Australia Barat (Warburton et al. 2000; Byrne et al. 2003; Rughkla et al. 2006; Tamla et al. 2012), Kepulauan Pasifik (Lhuillier et al. 2006) dan New Caledonia (Bottin et al. 2007) selama lebih dari dua dekade terakhir. Namun di tempat yang dipercaya sebagai center of origin cendana, yaitu Indonesia, penelitian masih sangat terbatas, baik di Indonesia bagian Tenggara (Brand 1994; Herawan et al. 2014; Indrioko \& Ratnaningrum 2015) maupun, terutama, Indonesia bagian barat (Ratnaningrum \& Indrioko, 2014, 2015; Indrioko \& Ratnaningrum 2016; Ratnaningrum \& Indrioko 2016; Ratnaningrum et al. 2016). Sebagai langkah sangat awal untuk mendeteksi adanya variasi pembungaan antar varian dan kondisi lingkungan yang berbeda, penelitian ini bertujuan untuk mengetahui variasi karakter pembungaan sebagai pengaruh berbedanya varian bunga dan struktur habitat di Gunung Sewu. Penelitian dilakukan pada tiga ras lahan yang mewakili setiap zona di Gunung Sewu yaitu ras lahan Nglanggeran (Zona Utara), Bleberan (Zona Tengah) dan Petir (Zona Selatan). Karakter pembungaan yang diamati meliputi fenologi (awal inisiasi bunga, frekuensi dan durasi pembungaan), kemasakan organ reproduksi, display serta struktur pembungaan, pada ketiga varian yang berbeda. Hasil penelitian ini diharapkan dapat berkontribusi dalam penyusunan strategi konservasi dan pemuliaan cendana, terutama yang berbasis maksimalisasi penyerbukan alam dan terkendali pada tingkat intra- maupun inter-varian.

\section{Bahan dan Metode}

\section{Lokasi dan Bahan Penelitian}

Geopark Gunung Sewu membentang dari barat ke timur sejauh $85 \mathrm{~km}$ meliputi tiga GeoArea yang terdiri dari tiga Propinsi yaitu Gunungkidul (Yogyakarta), Wonogiri (Jawa Tengah), dan Pacitan (Jawa Timur), dengan total area kurang lebih 1.300 $\mathrm{km}^{2}$. Kawasan Gunung Sewu memiliki dua musim yaitu musim penghujan pada bulan Oktober hingga Maret, dan musim kemarau pada April hingga September. Kawasan ini terbagi menjadi dua tipe iklim yaitu Aw, tipe semi-arid hingga arid yang dicirikan dengan musim kering yang panjang; dan tipe Am yang merepresentasikan kondisi intermediet antara iklim tropis dan sub tropis (Haryono \& Suratman 2010). Berdasarkan sejarah formasi geografisnya, GeoArea Gunungkidul terbagi menjadi tiga zona: (1) Zona Barat, dataran tinggi Batur Agung, 300 m hingga $800 \mathrm{~m} \mathrm{dpl}$; (2) Zona Tengah, dataran rendah Ledok Wonosari, $150 \mathrm{~m}$ hingga $300 \mathrm{~m} \mathrm{dpl}$; and (3) Zona Selatan, kawasan karst Pegunungan Seribu, o m hingga $200 \mathrm{~m} \mathrm{dpl}$.

Bahan penelitian adalah ras lahan cendana yang tumbuh secara alami pada berbagai tipe lanskap di GeoArea Gunungkidul, dan terbagi menjadi tiga grup (Tabel 1; Gambar 1). Grup pertama di Zona Barat meliputi ras lahan Nglanggeran dan Sriten di daerah dataran tinggi, dan Bejiharjo di dataran rendahnya. Grup kedua di Zona Tengah meliputi ras lahan Bleberan dan jurang Ngingrong. Di Zona Tengah ini juga terdapat beberapa area konservasi ex situ dengan jarak masing-masing kurang dari $10 \mathrm{~km}$. Area konservasi ini memiliki total luas lebih dari zo ha, yang tertua dibangun sejak tahun 1967, dan tersusun atas lebih dari 40 provenan dari Timor, NTT, dan Jawa. Grup ketiga merupakan kawasan karst di Zona Selatan yang meliputi ras lahan Semugih, Pucanganom, Petir, dan Botodayakan.

Pengertian ras lahan merujuk kepada definisi White et al. (2007): ras lahan merupakan hasil 
permudaan alam yang telah mampu bertahan hidup di suatu area tertentu di luar habitat alaminya, individu di dalamnya mampu bereproduksi hingga melampaui beberapa generasi, dan menghasilkan keturunan yang fertil. Terdapat tiga ras lahan yang diamati dalam penelitian ini yaitu ras lahan Nglanggeran yang mewakili Zona Utara (dataran tinggi Batur Agung); ras lahan Bleberan di Zona Tengah (Ledok Wonosari); serta ras lahan Petir di Zona Selatan (zona karst Pegunungan Seribu). Pemilihan ras lahan didasarkan pada posisi yang mewakili masing-masing zona pada kawasan Gunung Sewu dan ketersediaan materi pengamatan (Gambar 1).

\section{Pengamatan Fenologi Pembungaan dan Monitoring Data Iklim}

Fenologi pembungaan diamati berdasarkan modifikasi dari metode Owens et al. (1991) dan Ghazoul (1997). Masing-masing 5 pohon berbunga per varian bunga dipilih pada setiap populasi (total $\mathrm{N}=5$ individu x 3 varian x 3 ras lahan $=45$ individu); dan pada masing-masing pohon, 10 malai bunga diberi label. Pengamatan dilakukan setiap 3 hari sepanjang musim bunga, yang dimulai dari terbentuknya tunas reproduktif hingga tercapainya kemasakan buah dan biji. Pada puncak musim bunga, selama 5 hari berturut-turut pengamatan dilakukan selama 12 jam (o6.oo-18.oo) setiap hari, dimulai dari awal anthesis, anthesis sempurna, penyerbukan hingga pembuahan. Parameter fenologi pembungaan meliputi

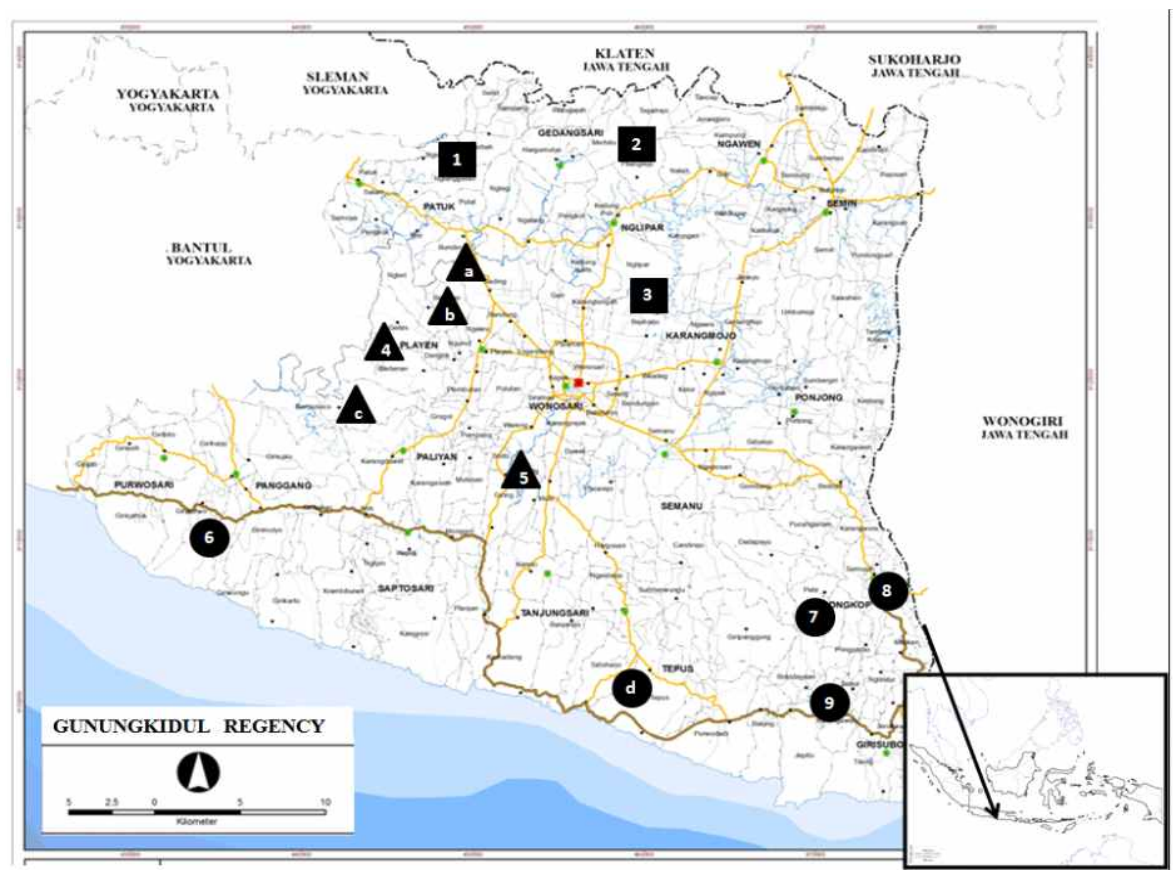

Gambar 1. Ras lahan cendana di GeoArea Gunungkidul, kawasan Gunung Sewu: Nglanggeran (1), Sriten (2) dan Bejiharjo (3) di Zona Utara; Bunder (a), Wanagama (b), Banyusoco (c), Bleberan (4), dan Mulo (5) di Zona Tengah; serta Pucanganom (6), Petir (7), Semugih (8), Botodayakan (9) dan Tepus (d) Zona Selatan. Lokasi yang ditandai dengan angka merupakan ras lahan, sedangkan huruf alfabet merepresentasikan area konservasi ex situ atau tanaman rehabilitasi. Pada tiap zona, tegakan cendana dinyatakan dalam bentuk bujur sangkar (Zona Barat), segitiga (Zona Tengah) dan lingkaran (Zona Selatan). Penelitian dilakukan pada ras lahan Nglanggeran (1), Bleberan (4) dan Petir (7) yang mewakili masing-masing zona di Gunung Sewu. (Sumber: Dinas Kehutanan DIY, 2015).

Figure 1. The sandalwood landraces in the Gunung Sewu Geopark. The first group (Northern Zone): Nglanggeran (1), Sriten (2) and Bejiharjo (3); the second group (Middle Zone): Bunder (a), Wanagama (b), Banyusoco (c), Bleberan (4), and Mulo (5); and the third group (Southern Zone): Pucanganom (6), Petir (7), Semugih (8), Botodayakan (9) and Tepus (d) landraces, respectively. The arabic numbers represents natural landraces, while the alphabetic fonts represents ex situ conservation areas. Within each of Gunung Sewu zone, sandalwood landraces are marked by squares (Northern Zone), triangles (Middle Zone) and circles (Southern Zone) shapes, respectively. Study was carried out on Nglanggeran (1), Bleberan (4) and Petir (7) landraces which were representing each of geographical zones. (Sources: Dinas Kehutanan DIY, 2015) 
Tabel 1. Karakteristik lokasi penelitian

Table 1. The characteristics of study sites

\begin{tabular}{|c|c|c|c|c|}
\hline Ras lahan & $\begin{array}{l}\text { Ketinggian dan } \\
\text { posisi geografis }\end{array}$ & Tipe iklim & $\begin{array}{l}\text { Tanah dan unit batuan } \\
\text { penyusun* }\end{array}$ & Karakteristik habitat \\
\hline $\begin{array}{l}\text { Nglangge- } \\
\text { ran; } 79 \cdot 3 \\
\text { ha }\end{array}$ & $\begin{array}{l}710 \mathrm{~m}-750 \mathrm{~m} \\
\mathrm{dpl} ; 7^{\circ} 5^{\circ} 28^{\prime \prime} \mathrm{S} \\
-110^{\circ} 32^{\prime} 55^{\prime \prime} \mathrm{E}\end{array}$ & $A m$ & $\begin{array}{l}\text { Didominasi latosol } \\
\text { dengan batuan vulkanik } \\
\text { dan sedimen, beberapa } \\
\text { tempat memiliki solum } \\
\text { agak dalam. }\end{array}$ & $\begin{array}{l}\text { Cendana pertama kali terdokumentasi sekitar } \\
\text { tahun 1970, saat ini tumbuh pada kelompok - } \\
\text { kelompok tegakan di sepanjang pegunungan } \\
\text { Nglanggeran, dalam asosiasi dengan vegetasi } \\
\text { pegunungan tropis. }\end{array}$ \\
\hline $\begin{array}{l}\text { Bleberan; } \\
52.9 \text { ha }\end{array}$ & $\begin{array}{l}\text { 15om - 170m } \\
\text { dpl; } 77^{\circ} \text { o' }^{\prime \prime} \text { S - } \\
110^{\circ} 50^{\prime} 75^{\prime \prime} \mathrm{E}\end{array}$ & $\begin{array}{l}\text { Intermediet } \\
\text { antara } A w \\
\text { dan } A m\end{array}$ & $\begin{array}{l}\text { Didominasi asosiasi } \\
\text { mediteran merah dan } \\
\text { grumosol dengan batuan } \\
\text { kapur/ limestone, } \\
\text { sebagian besar dengan } \\
\text { solum yang dalam. }\end{array}$ & $\begin{array}{l}\text { Cendana pertama kali terdokumentasi sekitar } \\
\text { tahun } 1970 \text { sepanjang daerah tangkapan air di } \\
\text { Sungai Oya, pada daerah lembah di zona } \\
\text { tengah. Terletak di s entra cendana di Gunung } \\
\text { Sewu, dikelilingi oleh beberapa area konservasi } \\
\text { ex situ yang juga dilewati oleh sungai yang } \\
\text { sama. }\end{array}$ \\
\hline $\begin{array}{l}\text { Petir; } 78 \\
\text { ha }\end{array}$ & $\begin{array}{l}70 m-100 m \text { dpl } \\
; 7^{\circ} 50^{\prime \prime} 60^{\circ} \text { S to } \\
110^{\circ} 60^{\prime} 15^{\prime \prime} \text { E }\end{array}$ & $A w$ & $\begin{array}{l}\text { Didominasi latosol } \\
\text { dengan batuan kapur/ } \\
\text { limestone, solum agak } \\
\text { dalam pada bagian } \\
\text { lembah dan sangat } \\
\text { dangkal pada kawasan } \\
\text { perbukitan kapur. }\end{array}$ & $\begin{array}{l}\text { Cendana pertama kali terdokumentasi sekitar } \\
\text { tahun } 1960 \text { pada kawasan perbukitan karst, saat } \\
\text { ini penyebarannya meliputi lebih dari } 20 \text { bukit. } \\
\text { Sebagian besar cendana dewasa terbentuk dari } \\
\text { pembiakan vegetatif alami dari trubusan akar. }\end{array}$ \\
\hline
\end{tabular}

*Simanjuntak (2002)

frekuensi pembungaan, (2) waktu dimulainya inisiasi bunga, dan (3) interval pembungaan. Inisiasi bunga merupakan saat tunas reproduktif mulai terdeteksi secara makroskopis untuk pertama kalinya. Frekuensi pembungaan merupakan jumlah episode pembungaan yang terjadi dalam suatu satuan waktu. Durasi pembungaan berhubungan dengan panjangnya interval waktu yang dibutuhkan untuk melangsungkan satu periode pembungaan.

Data iklim yang dimonitor adalah (1) temperatur udara, (2) kelembaban udara, (3) curah hujan, dan (4) status air tanah. Pengambilan data temperatur dan kelembaban udara dilakukan dengan thermohygrometer. Di tiap lokasi, pengukuran dilakukan pada tiga titik yang mewakili area ternaung, agak ternaung dan terbuka, pada tengah hari setiap satu minggu sekali. Data curah hujan sepanjang tahun 2014 hingga 2015 diperoleh dari Dinas Tanaman Pertanian dan Hortikultura Gunungkidul. Adapun data status air tanah diperoleh dengan mengambil sampel tanah pada kedalaman $10 \mathrm{~cm}$ pada tiga titik, yang mewakili area ternaung, agak ternaung dan terbuka di tiap lokasi, setiap tiga bulan sekali. Kedalaman $10 \mathrm{~cm}$ dipilih dengan pertimbangan bahwa rhizosfer cendana, tempat terjadinya aktivitas intensif dari sistem perakaran, terkonsentrasi pada kedalaman tersebut. Sampel tanah dikomposit kemudian diukur status airnya berdasarkan metode gravimetri.

\section{Penentuan Kemasakan Organ Reproduksi dan Longevity-nya}

Pengamatan organ reproduksi dilakukan berdasarkan modifikasi metode Owens et al. (1991). Masing-masing 3 pohon berbunga per varian bunga dipilih pada setiap ras lahan (total $\mathrm{N}=3$ individu $\times 3$ varian $\mathrm{x} 3$ ras lahan $=27$ individu). Pada masingmasing pohon, 3 malai bunga diberi label, dan pada masing-masing malai, dipilih 1 bunga tunggal secara acak (total $\mathrm{N}=1$ bunga $\times 3$ malai $\times 3$ individu $\times 3$ varian $\mathrm{x} 3$ ras lahan $=81$ bunga tunggal). Penentuan waktu dan longevity kemasakan organ reproduksi didasarkan pada hasil penelitian terdahulu (Ratnaningrum \& Indrioko 2014; Tabel 2) yang menunjukkan bahwa masa reseptif putik cendana ditandai dengan perubahan warna putik menjadi lebih terang, pembesaran pori-pori pada kepala putik, tangkai putik berangsur menjadi lurus, dan permukaan putik memproduksi sekresi. Kemasakan tepung sari ditandai dengan perubahan warna menjadi kuning 
Tabel 2. Tahapan perkembangan bunga cendana hingga menjadi buah masak

Table 2. The development of sandalwood flowers into mature fruits

\begin{tabular}{lc}
\hline \multicolumn{1}{c}{ Tahap Perkembangan } & Periode Waktu Perkembangan \\
\hline 1. Inisiasi tunas reproduktif & 4 hingga 7 minggu \\
2. Anthesis awal, kepala sari mulai masak & 2 hingga 4 hari \\
$\begin{array}{l}\text { 3. Anthesis sempurna, putik reseptif } \\
\text { 4.Penyerbukan dan pembuahan; bagian bunga bertransformasi menjadi buah; ovarium } \\
\text { berkembang membentuk buah muda berwarna hijau }\end{array}$ & 5 hingga 7 hari \\
$\begin{array}{l}\text { 5. Perkembangan buah hingga ukuran maksimal } \\
\begin{array}{l}\text { 6. Perkembangan buah hingga mencapai kemasakan, terjadi perubahan warna dari hijau } \\
\text { menjadi ungu gelap }\end{array}\end{array}$ & 5 hingga 10 hari \\
\hline
\end{tabular}

terang, dengan butiran tepung sari yang lebih lengket dan terlepas dari kepala sarinya.

Penelitian terdahulu menunjukkan bahwa perkembangan bunga cendana meliputi enam fase yaitu (1) inisiasi kuncup bunga dan perkembangannya hingga menjelang anthesis, (2) awal anthesis, bersamaan dengan kemasakan tepung sari, (3) anthesis sempurna, bersamaan dengan reseptivitas putik, (4) akhir anthesis, berkembangnya bunga terserbuki menjadi buah muda, (5) perkembangan buah muda hingga mencapai ukuran maksimal, dan (6) kemasakan buah dan biji (Tabel 2).

\section{Pengamatan Struktur dan Display Pembungaan}

Pengamatan struktur pembungaan dilakukan berdasarkan modifikasi dari metode Ghazoul (1997) dan Owens et al. (1991). Masing-masing 3 pohon berbunga per varian bunga dipilih pada setiap ras lahan (total $\mathrm{N}=3$ individu $\mathrm{x} 3$ varian $\mathrm{x} 3$ ras lahan $=27$ individu). Pada masing-masing pohon, 3 malai bunga diberi label, dan pada masing-masing malai, dipilih 5 bunga tunggal secara acak untuk pengamatan struktur bunga (total $\mathrm{N}=5$ bunga $\times 3$ malai $\times 3$ individu $\mathrm{x}_{3}$ varian $\mathrm{x} 3$ ras lahan $=405$ bunga tunggal). Struktur pembungaan yang diamati meliputi perubahan morfologi, ukuran, dan warna bagian-bagian bunga mulai dari awal hingga akhir anthesis. Bagian-bagian bunga diukur dengan kaliper dan penggaris. Penentuan warna bagian bunga didasarkan pada nilai Hue, Value, dan Chroma yang mengikuti standar baku Munsell Color Charts for Plant Tissues tahun 1977.
Display pembungaan diestimasi menggunakan modifikasi dari metode Herlihy dan Eckert (2005) dan Barrett et al. (2006). Display pembungaan, yang merepresentasikan keseluruhan karakter bunga yang berperan dalam menampilkan eksistensinya dalam populasi, merupakan kombinasi dari ukuran bunga, jumlah bunga per malai, jumlah malai per pohon, dan jumlah pohon yang berbunga dalam populasi. Jumlah bunga per malai dan jumlah malai per pohon dihitung dengan mengambil sampel masing-masing to pohon berbunga per varian pada setiap ras lahan (total $\mathrm{N}=10$ individu $\times 3$ varian $\times 3$ ras lahan $=90$ individu). Inventarisasi total jumlah individu cendana dewasa dan individu dewasa yang berbunga dilakukan mengikuti metode Rao et al. (2007), yang menggunakan metode Systematic Sampling with Random Start dengan intensitas sampling o,o1; tiap 1 ha luasan diwakili oleh 1 plot berukuran 10m x 1om.

\section{Hasil dan Pembahasan}

\section{Variasi Struktur, Ciri Kemasakan, dan Longevity Organ Reproduksi}

Pada tiap ras lahan yang diamati terdapat tiga varian cendana; masing-masing varian berbeda morfologi bunga dan daunnya. Karena ciri fisik yang paling mudah dibedakan dalam pengamatan morfologi ini adalah warna dan ukuran bunganya, maka untuk selanjutnya ketiga varian ini disebut varian bunga kuning besar (KB), bunga merah besar (MB), dan bunga merah kecil (MK) (Gambar 2). 
Tabel 3. Struktur pembungaan, ciri kemasakan dan longevity organ reproduksi ketiga varian cendana pada tiga ras lahan di Gunung Sewu. Identifikasi warna didasarkan pada parameter standar Hue, Value, dan Chroma dalam Munsell Color Charts for Plant Tissues (1977). Angka pertama yang diikuti huruf kapital melambangkan notasi Hue; angka kedua yang diikuti tanda "/" markadalah notasi Value; dan angka terakhir merupakan notasi Chroma.

Table3. Floral structures, maturity, and longevity of reproductive organs of the three sandalwood variants grown at the three landraces in Gunung Sewu. Color identification was based on the Hue, Value, dan Chroma parameter standards of "Munsell Color Charts for Plant Tissues" (1977). The first number followed by capital fonts represents Hue; the second number followed by "/" mark is Value; and the last number represents Chroma notations, respectively.

\begin{tabular}{|c|c|c|c|}
\hline \multirow{2}{*}{ Karakteristik } & \multicolumn{3}{|c|}{ Varian Bunga } \\
\hline & Merah Besar & Kuning Besar & Merah Kecil \\
\hline $\begin{array}{l}\text { Ukuran perigonium luar } \\
\text { (panjang } \mathrm{cm} x \text { lebar } \mathrm{cm} \text { ) }\end{array}$ & $(4$ hingga 5$) \times(2,5$ hingga 4$)$ & $(4$ hingga 5$) \times(2,5$ hingga 4$)$ & (2 hingga 3,5$) \times(1,5$ hingga 3$)$ \\
\hline - Panjang tangkai sari (mm) & 2 hingga 4 & 2 hingga 4 & 1 hingga 2 \\
\hline - Panjang tangkai putik (mm) & 2 hingga 4 & 2 hingga 4 & 1 hingga 3 \\
\hline $\begin{array}{l}\text { - Posisi tangkai putik } \\
\text { thd benang sari }\end{array}$ & Lebih rendah atau sejajar & Lebih rendah atau sejajar & Sejajar atau lebih tinggi \\
\hline \multicolumn{4}{|l|}{ Warna perigonium luar } \\
\hline - Awal anthesis & dusty white $(2.5 \mathrm{GY} 8 / 4)$ & yellowish white (5YR8/2) & dusty white (2.5GY8/4) \\
\hline - Anthesis sempurna & pale maroon $(2.5 \mathrm{R} 6 / 8)$ & pale orange $(2.5 \mathrm{YR} 7 / 6)$ & pale red $\left({ }_{5} \mathrm{R} 8 / 4\right)$ \\
\hline - Akhir anthesis & $\begin{array}{l}\text { maroon }\left({ }_{5} \mathrm{R}_{3} / 8\right) \text { - dark maroon } \\
\left({ }_{5} \mathrm{R}_{3} / 4\right)\end{array}$ & $\begin{array}{l}\text { yellowish brown }\left(10 \mathrm{R}_{5} / 10\right) \text { to } \\
\text { brownish orange }(2.5 \mathrm{YR} 6 / 8)\end{array}$ & dark red $\left(2.5 \mathrm{R}_{5} / 8\right)$ \\
\hline \multicolumn{4}{|l|}{ Warna stylus } \\
\hline - Awal anthesis & dusty white (2.5GY8/4) & yellowish white $(5 \mathrm{YR} 8 / 2)$ & dusty white $(2.5 \mathrm{GY} 8 / 4)$ \\
\hline - Anthesis sempurna & light maroon $\left(2.5 \mathrm{R}_{5} / 10\right)$ & pale yellow $(2.5 \mathrm{Y} 8 / 4)$ & pale red $\left({ }_{5} \mathrm{R} 8 / 4\right)$ \\
\hline - Akhir anthesis & reddish maroon $\left(2.5 \mathrm{R}_{4} / 10\right)$ & light orange $(7.5 \mathrm{YR} 8 / 4)$ & light maroon $\left({ }_{5} \mathrm{R}_{5} / 10\right)$ \\
\hline \multicolumn{4}{|l|}{ Warna stigma } \\
\hline - Awal anthesis & dusty white (2.5GY8/4) & yellowish white (5YR8/2) & dusty white (2.5GY8/4) \\
\hline - Anthesis sempurna & whitish maroon $\left(2.5 \mathrm{R}_{7} / 8\right)$ & pale orange $(7.5 \mathrm{YR} 8 / 6)$ & whitish red $(2.5 \mathrm{R} 8 / 4)$ \\
\hline - Akhir anthesis & pale maroon $\left(2.5 \mathrm{R}_{7} / 8\right)$ & brownish orange (2.5YR6/8) & dark orange $(7.5 \mathrm{YR} 8 / 4)$ \\
\hline \multicolumn{4}{|l|}{ Warna kepala sari } \\
\hline - Awal anthesis & whitish yellow (2.5Y8/6) & whitish yellow $(2.5 \mathrm{Y} 8 / 6)$ & whitish yellow (2.5Y8/6) \\
\hline - Anthesis sempurna & dusty orange $\left(2.5 \mathrm{YR}_{7} / 8\right)$ & dark orange (5YR6/10) & dusty orange $\left(2.5 \mathrm{YR}_{7} / 8\right)$ \\
\hline - Akhir anthesis & orange $\left(7.5 \mathrm{YR}_{7} / 10\right)$ & dark brown $\left({ }_{5} \mathrm{R}_{3} / 6\right)$ & dark orange $\left(5 \mathrm{YR}_{7} / 10\right)$ \\
\hline -Longevity anthesis (hari) & 6 hingga 10 & 6 hingga 11 & 9 hingga 14 \\
\hline $\begin{array}{l}\text { - Kemasakan tepung sari } \\
\text { (hari setelah anthesis) }\end{array}$ & Bersamaan & Bersamaan & Bersamaan \\
\hline $\begin{array}{l}\text { - Reseptivitas putik } \\
\text { (hari setelah anthesis) }\end{array}$ & 2 hingga 4 & 2 hingga 4 & 2 hingga 4 \\
\hline - Longevity tepung sari (hari) & 2 hingga 5 & 2 hingga 5 & 4 hingga 7 \\
\hline - Longevity putik (hari) & 4 hingga 6 & 4 hingga 7 & 5 hingga 10 \\
\hline
\end{tabular}

Penelitian ini menjumpai perbedaan struktur pembungaan (morfologi, ukuran dan warna bagianbagian bunga), ciri kemasakan, serta longevity organ reproduksi antar varian bunga (Gambar 3; Tabel 3). Walaupun demikian, dalam varian yang sama, tidak dijumpai perbedaan struktur, ciri kemasakan serta longevity organ reproduksi antar ras lahan.

\section{Variasi Warna Perigonium dan Organ Repro- duksi Antar Varian Bunga}

Perbedaan warna bunga dan organ reproduksi terutama teramati pada fase anthesis sempurna
(Gambar 3; Tabel 3). Awal anthesis hanya menunjukkan sedikit perbedaan warna antar varian bunga. Putik dan perigonium luar pada varian $\mathrm{KB}$ menampilkan warna yellowish white (5 $\mathrm{YR} 8 / 2)$, sedangkan pada kedua varian lainnya bagian tersebut berwarna dusty white (2.5GY8/4). Fase awal anthesis ini terjadi bersamaan dengan kemasakan tepung sari, yang ditandai dengan warna whitish yellow (2.5GY8/6) dan peningkatan kelekatan tepung sari, serta mulai terlepasnya butiran tepung sari dari kepala sari. Pada fase selanjutnya, varian KB mengalami perubahan 

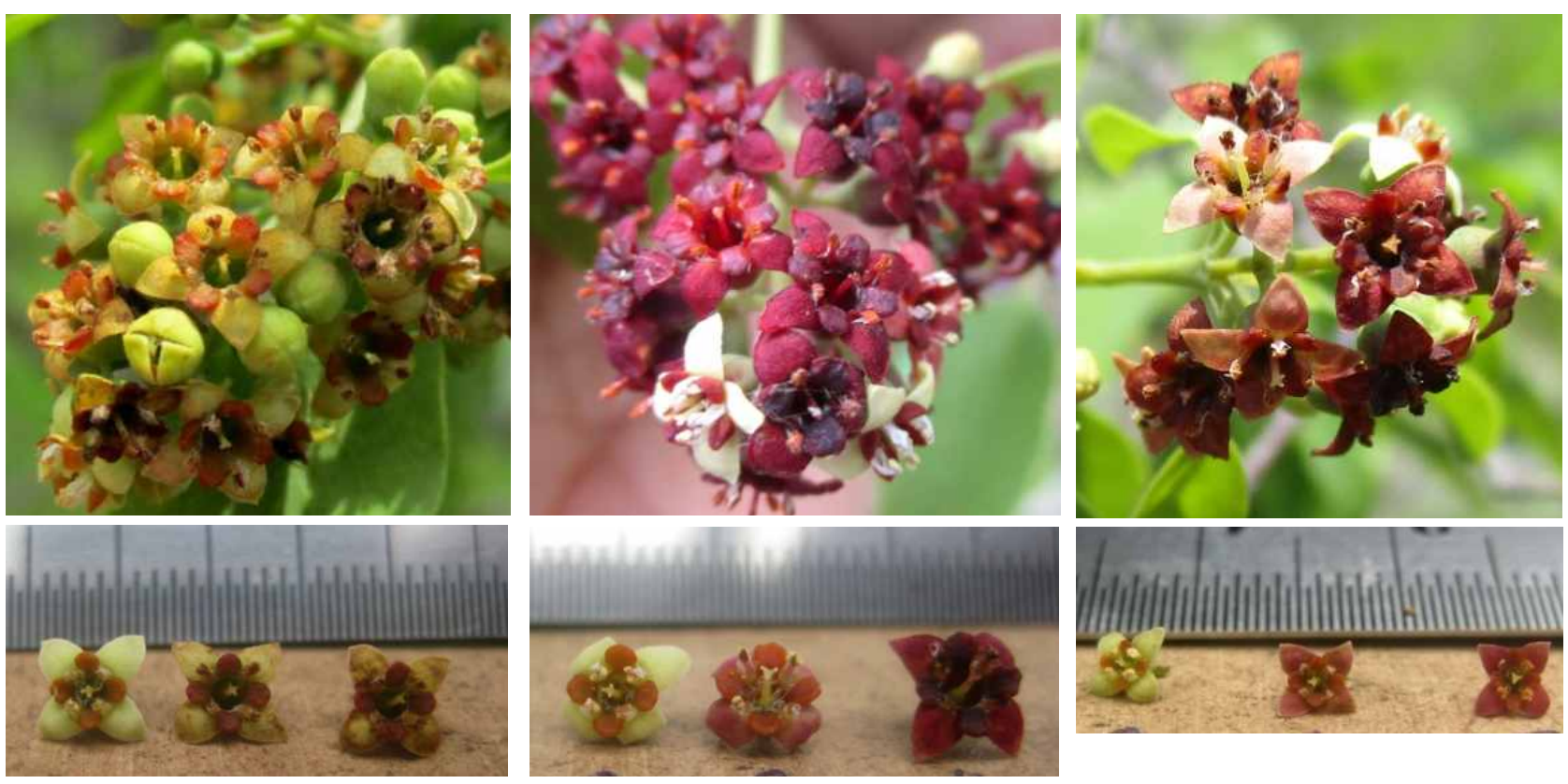

Gambar 2. Ketiga varian cendana pada tiga ras lahan di Gunung Sewu: varian Kuning Besar (kiri), Merah Besar (tengah) dan Merah Kecil (kanan).

Figure 2. The three of sandalwood flower variants grown in the three landraces of Gunung Sewu: Yellow Big (left), Red Big (middle) and Red Small (right) variants, respectively.

warna perigonium luar mulai dari pale orange (2.5YR7/6), yellowish brown (10R5/10) hingga brownish orange (2.5YR6/8) selama fase intermediet, anthesis sempurna hingga akhir anthesis. Pada varian MB perubahan warna ini adalah pale maroon (2.5 $\mathrm{R} 6 / 8)$, maroon (5 $\left.\mathrm{R}_{3} / 8\right)$ hingga dark maroon $\left.{ }_{5} \mathrm{R}_{3} / 4\right)$; sedangkan pada varian MK perubahan warna dimulai dari pale red (5R8/4) hingga dark red (2.5 $\left.\mathrm{R}_{5} / 8\right)$. Pada fase anthesis sempurna, terjadi pula perubahan warna tangkai dan kepala putik, yang mengikuti perubahan warna perigonium luar. Perubahan warna putik ini diindikasikan sebagai awal kemasakan atau reseptivitasnya. Bersamaan dengan fase reseptivitas putik ini, tepung sari telah kehilangan viabilitasnya, dan kepala sari telah berangsur mengering. Perubahan warna putik menjadi lebih gelap, yang biasanya terjadi pada fase akhir anthesis, mengindikasikan berakhirnya masa reseptif, yang diikuti oleh gugurnya organ-organ bunga.

Menurut Jones dan Little (1983), faktor edafis seperti hara dan kelembaban berperan dalam menentukan warna bunga. Hara berpengaruh terhadap proses produksi, translokasi, dan akumulasi zat warna seperti antosianin dan fikoeritrin. Kelembaban lebih berpengaruh terhadap kuat-lemahnya spektrum warna yang dapat diekspresikan oleh bunga. Pada kasus lain, perbedaan warna bunga lebih dipengaruhi oleh ketinggian tempat, yang membawa konsekuensi berbedanya intensitas cahaya dan suhu. Bunga Ipomopsis aggregata berwarna merah di tempat dengan pencahayaan penuh, dan putih atau merah jambu pucat di tempat yang lebih ternaung. Sementara itu, perbedaan warna bunga pada tanaman Encelia farinosa ternyata lebih dipengaruhi oleh curah hujan dan kelembaban air tanah.

Namun, perbedaan warna bunga cendana yang dijumpai pada penelitian ini diduga lebih merupakan kendali genetik. Hal ini terbukti dari munculnya ketiga varian bunga tersebut pada seluruh ras lahan, walaupun setiap ras lahan terletak pada ketinggian dan kondisi lingkungan yang berbeda. Perbedaan suhu udara, kelembaban udara, curah hujan, dan status air tanah yang diukur pada penelitian ini, sebagaimana perbedaan ketinggian tempat dan jenis tanah antar ras lahan, tidak mengakibatkan berbedanya warna bunga dalam varian yang sama. Seluruh varian, beserta keturunannya, selalu 
(1)
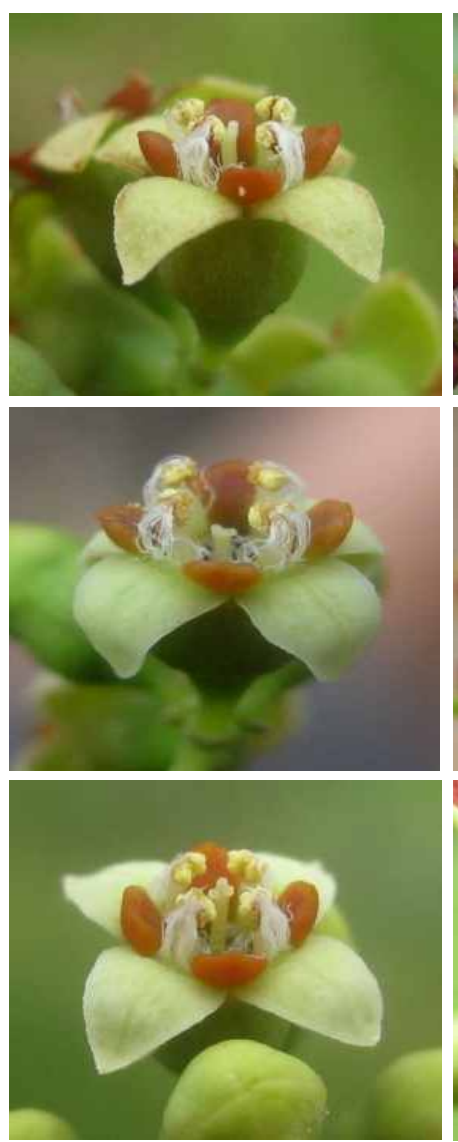

(2)
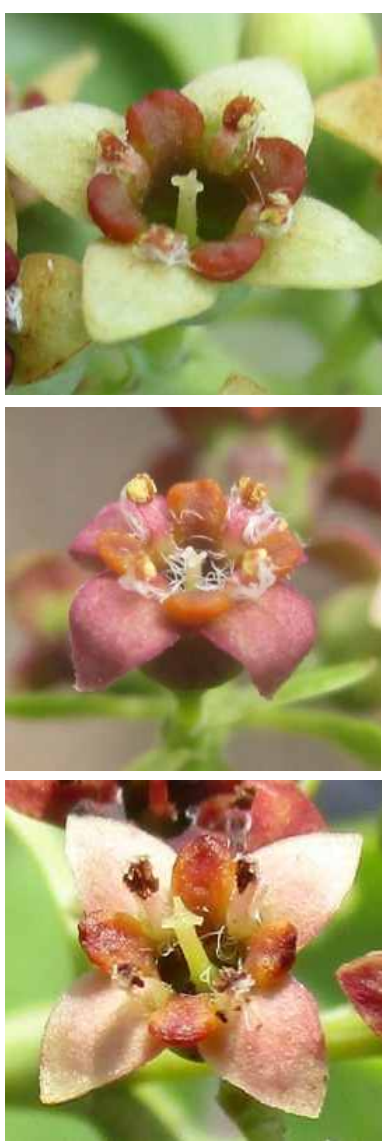

(3)
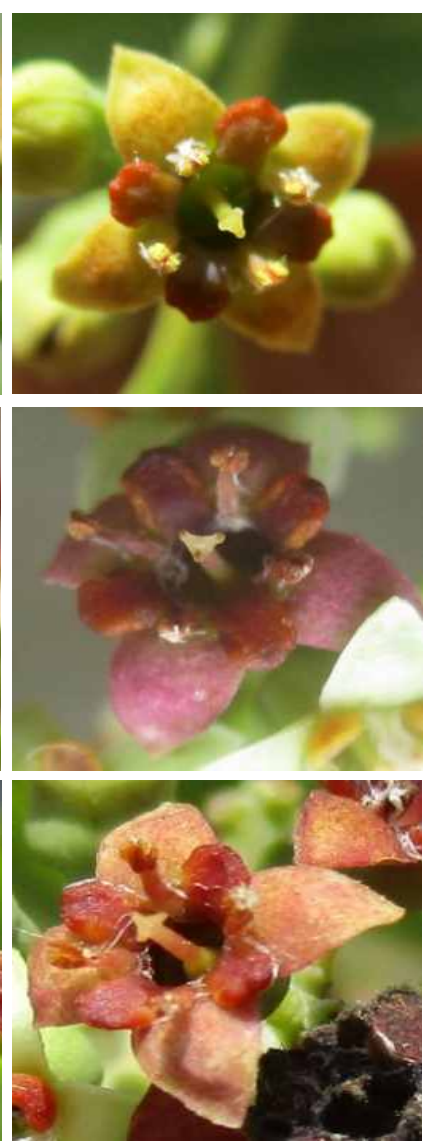

(4)
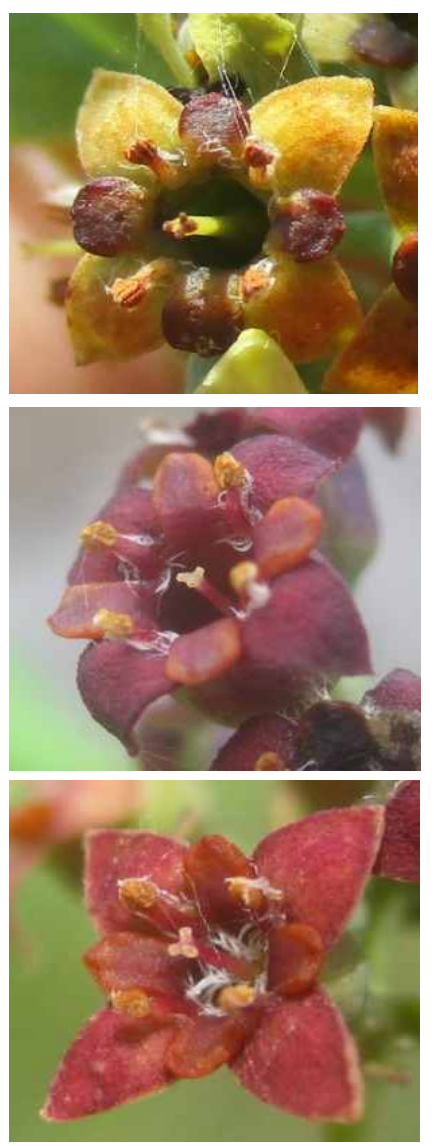

Gambar 3. Perubahan warna dan morfologi ketiga varian bunga cendana selama periode anthesis: awal anthesis (1), anthesis intermediet (2), anthesis sempurna (3) dan akhir anthesis (4); pada varian Kuning Besar (atas), Merah Besar (tengah), dan Merah Kecil (bawah). Identifikasi warna didasarkan pada parameter standar Hue, Value, dan Chroma dalam Munsell Color Charts for Plant Tissues (1977).

Figure 3. The changes on floral color and morphology of the three sandalwood variants during anthesis: early anthesis (1), intermediate anthesis (2), fully anthesis (3) and late anthesis (4); in the Yellow Big (top), Red Big (middle) and Red Small (bottom) variants, respectively. Color identification was based on the Hue, Value, dan Chroma parameter standards of "Munsell Color Charts for Plant Tissues" (1977).

memproduksi warna bunga yang sama, walaupun tumbuh pada ketinggian tempat maupun kondisi lingkungan yang bervariasi.

Bunga dari varian $\mathrm{KB}$ akan selalu berwarna kekuningan (yellowish) di ras lahan mana pun, dan keturunan vegetatif yang dihasilkan dari akar horizontalnya juga selalu menghasilkan bunga dengan warna yang sama. Hal yang sama juga dijumpai pada varian MK yang berwarna lebih merah (red), dan varian MB yang lebih didominasi warna marun gelap (dark maroon). Hal serupa dijumpai pada enam varian S. album di India Selatan (Rao et al. 2007), yang masing-masing memiliki karakteristik bunga dan daun yang spesifik, walaupun tumbuh pada kondisi lingkungan dan geografis yang berbeda-beda.

Sementara itu, jenis $S$. album di Australia selalu berwarna merah (red) hingga marun (maroon), sedangkan warna kekuningan (yellowish) merupakan ciri spesifik bunga $S$. spicatum dan S. lanceolatum (Tamla et al. 2012). Namun, berbeda dengan hasil penelitian tersebut, Brand (1994) menjumpai dominasi warna yellowish pada S. album di Australia.

Sehubungan dengan perbedaan warna bunga ini, Jones dan Little (1983) mengajukan teori competition for pollination. Perbedaan warna dan struktur bunga dikendalikan oleh suatu mekanisme genetis untuk dapat berkompetisi, agar dapat melangsungkan 
penyerbukan dalam kuantitas dan kualitas yang memadai. Hal ini dapat berupa kompetisi untuk memperoleh preferensi agen penyerbuk atau melakukan transfer tepung sari interspesifik. Dibutuhkan penelitian lebih lanjut pada tingkatan molekuler untuk dapat membuktikan perbedaan genetis antar varian bunga S. album.

Dalam penelitian ini, setiap varian juga menampilkan perubahan warna bunga seiring dengan berubahnya fase perkembangan (Gambar 3). Perubahan kombinasi warna bunga sepanjang fase pembungaan merupakan sinyal yang digunakan oleh agen penyerbuk untuk mendeteksi ketersediaan atraktan (Barrett et al. 2006). Munculnya warna bunga tertentu diduga menjadi pertanda ketersediaan jenis atraktan tertentu, seperti nektar dan tepung sari (Jones \& Little 1983; Ghazoul 1997).

Jenis Anthophora dari ordo Hymenoptera, yang merupakan agen penyerbuk Pulmonaria sp, hanya mendatangi bunga berwarna merah jambu dari fase awal anthesis, dan sama sekali tidak menyentuh bunga-bunga fase akhir anthesis yang berwarna biru. Sementara itu, bunga biru dari fase akhir anthesis lebih banyak dikunjungi oleh penyerbuk dari jenis Mertensia dan Oxytropis.

Hal yang sama teramati pada tanaman Helleborus niger yang didominasi oleh lebah saat mahkota bunganya berwarna putih pada fase awal anthesis. Warna putih ini mengindikasikan aktifnya nektari, kelenjar penghasil nektar yang ada di bagian atas kelopak bunga; dan menjadi pertanda bagi pemakan nektar bahwa makanan tersebut sedang tersedia dalam kelimpahan yang tinggi. Kunjungan lebah berakhir ketika mahkota berubah menjadi hijau muda, yang menandakan berakhirnya fase anthesis.

Munculnya bunga dengan warna yang berbeda juga teramati pada Cirsium palustre. Lebah Bombus lapponicus hanya mengunjungi bunga putih yang tumbuh pada tempat yang lebih tinggi; dan sama sekali tidak menyentuh bunga ungu pada tempat yang lebih rendah. Hal serupa dijumpai pada bunga Raphanus raphanistrum yang tumbuh pada tempat berbeda. Ngengat dan lalat cenderung mengunjungi bunga kuning buram keunguan, sedangkan lebah Bombus spp memilih bunga putih (Jones \& Little 1983).

Bunga cendana diserbuki oleh serangga dari ordo Hymenoptera, Lepidoptera, dan Diptera (SindhuVereendra \& Anantha-Padmanabha 1996; Suma \& Balasundaran 2003; Ratnaningrum \& Indrioko, 2014; da Silva et al. 2016), walaupun di beberapa tempat dijumpai pula Coleoptera dan Hemiptera dalam intensitas yang tidak terlalu tinggi (Ratnaningrum et al. 2016; da Silva et al. 2016).

Penelitian terdahulu pada berbagai provenan cendana di Wanagama menunjukkan bahwa warna bunga mempengaruhi jenis dan intensitas agen penyerbuk. Bunga dari provenan Timor yang berukuran lebih kecil dan berwarna lebih pucat dikunjungi oleh lebih banyak Diptera dan Lepidoptera dari kelompok ngengat. Sementara itu, ras lahan Jawa yang berbunga lebih besar dan berwarna lebih cerah didominasi oleh Hymenoptera dan Lepidoptera dari kelompok kupu-kupu (Ratnaningrum \& Indrioko 2014). Dalam penelitian ini, ketiga varian cendana memiliki ukuran dan warna bunga yang berbeda. Hal ini dapat membawa konsekuensi berbedanya jenis dan intensitas kunjungan agen penyerbuk, yang dapat berdampak pada berbedanya produksi biji (Indrioko \& Ratnaningrum 2016).

Ketiga varian bunga di Gunung Sewu terbukti memperoleh kunjungan agen penyerbuk dengan jenis dan intensitas yang berbeda (Ratnaningrum et al. 2016). Dibutuhkan penelitian lebih lanjut untuk mengetahui preferensi agen penyerbuk terhadap masing-masing varian bunga, dampaknya terhadap tingkat perkawinan sendiri dan silang, serta keberhasilan produksi bijinya. 


\section{Variasi Struktur (Ukuran dan Posisi) Bagian-Bagian Bunga serta Longevity Organ Reproduksi}

Selain variasi warna bagian-bagian bunga, teramati pula perbedaan struktur bunga antar varian, yang meliputi perbedaan ukuran dan posisi bagian-bagian bunga (Tabel 3). Secara umum, varian MB dan KB memiliki ukuran perigonium lebih besar dan organ reproduksi yang lebih panjang, dengan posisi putik sejajar atau lebih rendah dari benang sari. Varian MK berukuran lebih kecil dengan posisi putik sejajar atau lebih tinggi dari benang sari.

Perbedaan durasi waktu anthesis disebabkan oleh berbedanya longevity tepung sari dan putik antar varian (Tabel 3). Bunga cendana bertipe protandridikogami, organ reproduksi jantan masak terlebih dahulu daripada betina. Tepung sari masak bersamaan dengan awal anthesis, sedangkan putik baru mencapai reseptif beberapa hari kemudian, saat tepung sari mulai kehilangan viabilitasnya. Varian MB melangsungkan periode anthesis selama 6-10 hari. Putik mencapai reseptif 2-4 hari setelah anthesis, dengan longevity 4-6 hari, sedangkan tepung sari viabel mulai dari awal anthesis hingga 2-5 hari sesudahnya. Durasi yang sama terjadi pada varian KB, dengan sedikit perbedaan pada longevity putik yaitu 4-7 hari. Sementara itu, varian MK memiliki periode anthesis lebih panjang, yaitu 9-14 hari. Pada varian ini, putik mencapai reseptif 2-4 hari setelah anthesis, dengan longevity 5-10 hari, sedangkan tepung sari viabel mulai dari awal anthesis hingga 4-7 hari sesudahnya.

Tanaman berevolusi dan melangsungkan berbagai strategi perkawinan untuk meningkatkan keberhasilan reproduksinya (Barrett et al. 2006), dan hal ini juga terjadi pada familia Santalaceae (Harbaugh \& Baldwin 2007). Modifikasi struktur dan fungsi bagian bunga ditujukan untuk meningkatkan kemampuan reproduksi (Barrett et al. 2006) dan interaksi dengan agen penyerbuk (Herlihy \& Eckert 2005). Mekanisme pemisahan organ reproduksi jantan dan betina (separation of sexes), baik secara temporal maupun spasial, ditujukan untuk meminimalkan perkawinan sendiri (Barrett et al. 2006).

Temporal separation of sexes merujuk kepada mekanisme alami melalui pengaturan waktu kematangan organ reproduksi, agar organ jantan dan betina tidak masak dalam waktu yang bersamaan. Seluruh varian pada penelitian ini mencapai kemasakan tepung sarinya lebih awal, bersamaan dengan mekarnya bunga; sementara reseptivitas putik dicapai beberapa saat sesudahnya menjelang fase anthesis sempurna, tepat pada saat tepung sari mulai kehilangan viabilitasnya. Varian MK memiliki longevity putik dan tepung sari yang lebih lama. Penelitian serupa pada areal konservasi ex situ cendana di Wanagama (Ratnaningrum \& Indrioko 2014) juga menjumpai tipe protandri dikogami pada seluruh provenan dari Timor maupun ras lahan dari Jawa. Ras lahan dari Jawa yang didominasi oleh varian MB memiliki longevity organ reproduksi yang lebih singkat dibanding provenan dari Timor yang didominasi varian MK.

S. album memiliki longevity organ reproduksi yang lebih panjang (7-9 hari) (Rughkla et al. 2006; Ratnaningrum \& Prehaten 2005; Tamla et al. 2012; Ratnaningrum \& Indrioko 2014), dibandingkan dengan spesies cendana lainnya seperti $S$. austrocaledonium (24-48 jam) dan S. lanceolatum (12-24 jam) (Tamla et al. 2012). Keberadaan sekresi ekstraseluler pada kepala putik, yang merepresentasikan reseptivitasnya, mencapai kelimpahan maksimal sehari setelah anthesis (Tamla et al. 2012). Namun, keberadaan sekresi ini teramati dalam kisaran waktu yang lebih lama, hingga 2-3 hari berikutnya, pada kondisi lingkungan yang lebih dingin dan lembab (Sindhu-Vereendra \& AnanthaPadmanabha 1996; Tamla et al. 2012; Ratnaningrum \& Indrioko 2015).

Spatial separation of sexes adalah pemisahan posisi atau letak (space) organ reproduksi pada bunga 
hermafrodit, yang merupakan mekanisme alami untuk meminimalkan perkawinan sendiri (Barrett et al. 2006). Pada penelitian ini, teramati perbedaan struktur bunga antar varian, yang meliputi perbedaan ukuran dan posisi bagian-bagian bunga. Penelitian serupa di Wanagama (Ratnaningrum \& Indrioko 2014) juga menjumpai tipe heterostili pada seluruh provenan dari Timor maupun ras lahan dari Jawa. Ras lahan dari Jawa yang didominasi oleh varian MB memiliki tangkai sari yang hampir sama panjangnya dengan putik, sedangkan provenan dari Timor yang didominasi varian MK memiliki tangkai sari 1,5 kali lebih panjang dari pada putik. Polimorfisme juga dijumpai pada sebagian besar bunga cendana di India. Sebagian bunga memiliki putik yang lebih rendah dari pada benang sari; sebagian lagi putiknya justru lebih tinggi atau sejajar (Sindhu-Vereendra \& Anantha-Padmanabha 1996; Rughkla et al. 2006; Suma \& Balasundaran 2003; Rao et al. 2007).

Sebenarnya, struktur bunga cendana sangat kecil dan secara visual tidak terlalu menarik, dengan perianthium yang tidak terdiferensiasi, serta nektar dan tepung sari yang jumlahnya sangat sedikit (Sindhu-Vereendra \& Anantha-Padmanabha 1996; Rughkla et al. 2006). Struktur bunga cendana yang berukuran kecil ini merupakan karakteristik tanaman yang secara alami memiliki kecenderungan untuk melakukan perkawinan sendiri (Herlihy \& Eckert 2005; Barrett et al. 2006). Karena itu, jika mengacu pada teori ini, seharusnya bunga cendana memiliki kecenderungan sebagai inbreeder. Namun, struktur dan kedudukan organ reproduksinya menguatkan dugaan bahwa cendana adalah outbreeder (Sindhu-Vereendra \& Anantha-Padmanabha 1996; Rughkla et al. 2006; Suma \& Balasundaran 2003; Rao et al. 2007; Tamla et al. 2012; Ratnaningrum \& Indrioko 2014). Dalam hal ini, dapat diimplikasikan bahwa struktur heterostili merupakan mekanisme alami pada tanaman untuk menghindarkan terjadinya penyerbukan sendiri.
Pada penelitian ini, perbedaan struktur dan longevity organ reproduksi antar varian teramati konsisten di setiap ras lahan. Hal ini mengindikasikan adanya kendali genetik. Di samping itu, perbedaan ini juga mengakibatkan sulitnya ketiga varian ini untuk dapat berkawin silang di alam. Varian MK yang paling berbeda struktur reproduksi dan longevity-nya, mengindikasikan adanya mekanisme hambatan perkawinan (mating barriers), yang semakin menyulitkannya untuk berkawin silang dengan kedua varian lainnya. Sementara itu, varian MB dan KB memiliki kesamaan struktur dan longevity organ reproduksi, sehingga masih dimungkinkan untuk berkawin silang. Sehubungan dengan hal itu, selain studi molekuler, dibutuhkan penelitian lebih lanjut untuk mengetahui crossability masing-masing varian dalam persilangan inter- dan intraspesifik.

Perbedaan ukuran reproduksi, dalam hal ini panjang tangkai putik, juga teramati mengakibatkan gagalnya pembuahan pada jenis Ipomopsis aggregata. Ukuran mahkota bunga, panjang tangkai sari, dan posisi kepala sari berkorelasi positif dengan intensitas transfer tepung sari (Wolf et al. 2001). Sementara itu, Fernandez et al. (2009) membuktikan bahwa perbedaan ukuran organ reproduksi pada 25 jenis tumbuhan di hutan lindung Chaco Serrano Forest, Argentina, berpengaruh terhadap berbedanya keberhasilan reproduksi. Secara umum, tumbuhan dengan bunga yang lebih besar dan organ reproduksi heterostili mampu memproduksi lebih banyak biji.

Selain adanya kemungkinan bahwa variasi struktur organ reproduksi cendana dikendalikan oleh faktor genetik, perubahan lingkungan juga mungkin berpengaruh. Dalam penelitian ini, pengukuran struktur organ reproduksi dilakukan pada dua musim yang berbeda, yaitu musim hujan dan kemarau. Namun, tidak dijumpai perbedaan struktur organ reproduksi cendana antara kedua musim tersebut. Terjadinya beberapa anomali iklim, seperti kekeringan yang mendadak di tengah musim hujan, serta kekeringan yang memperpanjang musim 
kemarau, diduga berpengaruh terhadap hal ini. Pada penelitian sebelumnya, musim hujan yang panjang terbukti menghasilkan ukuran benang sari dan putik yang juga lebih panjang (Ratnaningrum \& Indrioko 2014). Hal ini diduga merupakan pengaruh peningkatan status air tanah yang mengaktivasi proses regenerasi, perluasan dan perpanjangan sel (White et al. 2007). Penambahan ukuran organ reproduksi sebagai akibat dari berkurangnya ukuran populasi dan agen penyerbuk juga dijumpai pada 25 tanaman di Cordoba, Argentina (Fernandez et al. 2009), dan diduga hal ini merupakan mekanisme alami untuk dapat menarik agen penyerbuk dan meningkatkan probabilitas keberhasilan reproduksi.

\section{Variasi Display Pembungaan antar Varian dan Ras Lahan}

Komponen display pembungaan, yaitu jumlah bunga per malai, jumlah malai per pohon, jumlah total bunga per pohon, dan jumlah pohon berbunga, teramati berbeda antar ras lahan, namun tidak berbeda nyata antar varian bunga. Dua di antara komponen display perbungaan, yaitu jumlah total bunga per pohon dan jumlah pohon berbunga, memberikan perbedaan paling signifikan antar ras lahan (Tabel 4).

Secara umum, varian MK menghasilkan jumlah bunga terbanyak per malai (berkisar antara 17 hingga 35 kuntum bunga), diikuti oleh varian KB (berkisar antara 19 hingga 30 kuntum bunga) dan MB (berkisar antara 19 hingga 26 kuntum bunga). Ras lahan Nglanggeran memproduksi paling banyak bunga MK dan MB per malai (35 dan 26 kuntum), sedangkan pada ras lahan Bleberan, varian KB menghasilkan jumlah bunga terbanyak per malai (30 kuntum bunga).

Jumlah malai per pohon juga sangat bervariasi antar varian dan ras lahan, dan hal ini tampaknya berkaitan erat dengan umur pohon induk. Pohon induk berumur lebih tua memproduksi lebih banyak malai per pohon. Varian MK menghasilkan jumlah malai terbanyak per pohon (berkisar antara 49 hingga 259 malai), diikuti oleh varian KB (berkisar antara 39 hingga 101 malai) dan MB (berkisar antara 43 hingga 62 malai). Pohon-pohon di Nglanggeran memproduksi paling banyak malai untuk ketiga varian bunga (MK 259, MB 62, KB 101 malai), dikarenakan sebagian besar pohon berumur lebih dari 40 tahun, yang dapat diprediksi dari tinggi dan diameter pohon pada jenis yang slow growing ini (Kepala Dusun Tlogo Nglanggeran, komunikasi pribadi). Sementara itu, pohon-pohon berbunga di dua ras lahan lainnya, terutama Petir, merupakan hasil regenerasi vegetatif trubusan akar dari pohon-pohon yang lebih besar, masih berumur muda (Kepala Desa Petir, komunikasi pribadi) dan karenanya hanya mampu menghasilkan sedikit malai per pohon.

Jumlah total bunga per pohon merupakan hasil perkalian antara jumlah bunga per malai dengan jumlah malai per pohon. Karena itu, varian dengan nilai tertinggi pada kedua komponen tersebut akan menghasilkan jumlah total bunga terbanyak per pohon. Ras lahan Nglanggeran memproduksi paling banyak bunga MK dan MB per pohon (total 9.186 dan 1.667 kuntum), sedangkan pada ras lahan Bleberan, jumlah bunga terbanyak adalah varian KB (2.457 kuntum per pohon).

Jumlah total bunga dalam ras lahan merupakan hasil perkalian antara jumlah total bunga per pohon dengan jumlah seluruh pohon berbunga dalam ras lahan. Tiap ras lahan didominasi oleh varian yang berbeda, jumlah, dan umur pohon yang sangat bervariasi. Hal ini mengakibatkan sangat bervariasinya jumlah total bunga antar varian maupun ras lahan. Ras lahan Petir, dengan ukuran populasi terbesar, ditumbuhi oleh lebih dari 4.000 batang pohon berbunga. Tegakan cendana di Petir didominasi oleh varian MB (2.340 pohon), sehingga walaupun jumlah bunga per malai dan jumlah malai per pohon tidak banyak, namun ras lahan ini menghasilkan total bunga MB terbanyak (hampir 2 juta kuntum) dalam satu periode pembungaan. 
Tabel 4. Karakteristik display pembungaan antar varian bunga pada ketiga ras lahan di Gunung Sewu.

F ratio dan P values berasal dari uji analysis of variance (ANOVA) yang dilakukan antar ras lahan dan antar varian.

Tanda bintang $\left(^{*}\right)$ menunjukkan beda nyata pada $\mathrm{P}<0.05$.

Table 4. Floral display characteristics of the three floral variants grown in the three landraces of Gunung Sewu.

$F$ ratio and $P$ values was obtained from the analysis of variance (ANOVA) test conducted among variants and landraces. The star marks $\left.{ }^{*}\right)$ represent significancy at $\mathrm{P}<0.05$.

\begin{tabular}{|c|c|c|c|c|c|}
\hline $\begin{array}{l}\text { Ras lahan dan } \\
\text { varian bunga }\end{array}$ & $\begin{array}{l}\text { Rerata jumlah } \\
\text { bunga per malai }\end{array}$ & $\begin{array}{l}\text { Rerata jumlah malai } \\
\text { per pohon }\end{array}$ & $\begin{array}{l}\text { Jumlah total bunga } \\
\text { per pohon }\end{array}$ & $\begin{array}{l}\text { Jumlah pohon } \\
\text { berbunga }\end{array}$ & $\begin{array}{c}\text { Jumlah total bunga } \\
\text { dalam ras lahan }\end{array}$ \\
\hline \multicolumn{6}{|l|}{ Antar ras lahan } \\
\hline \multicolumn{6}{|l|}{ Nglanggeran } \\
\hline - Var. Merah Kecil & 35,40 & 259,50 & 9.186 & 28 & 257.216 \\
\hline - Var. Merah Besar & 26,56 & 62,75 & 1.667 & 57 & 95.007 \\
\hline - Var. Kuning Besar & 19,88 & 101,75 & 2.022 & 56 & 113.247 \\
\hline Rerata & 27,28 & 141,33 & $4.291,67$ & 47 & $155.156,67$ \\
\hline \multicolumn{6}{|l|}{ Bleberan } \\
\hline - Var. Merah Kecil & 17,69 & 59,80 & 1.058 & 64 & 67.703 \\
\hline - Var. Merah Besar & 21,55 & 61,00 & 1.315 & 39 & 51.267 \\
\hline - Var. Kuning Besar & 30,53 & 80,50 & 2.457 & 26 & 63.888 \\
\hline Rerata & 23,26 & 67,10 & 1.610 & 43 & $60.952,67$ \\
\hline \multicolumn{6}{|l|}{ Petir } \\
\hline - Var. Merah Kecil & 22,68 & 49,67 & 1.127 & 1.404 & 1.581 .754 \\
\hline - Var. Merah Besar & 19,53 & 43,20 & 844 & 2.340 & 1.974 .249 \\
\hline - Var. Kuning Besar & 21,38 & 39,00 & 834 & 936 & 780.273 \\
\hline Rerata & 21,20 & 43,96 & 935 & 1.560 & $1.445 .425,33$ \\
\hline F stat. & 0,809 & 2,114 & 1,527 & $13,456^{*}$ & $14,236^{*}$ \\
\hline P value & 0,488 & 0,202 & 0,291 & o,oo6* & $0,005^{*}$ \\
\hline \multicolumn{6}{|l|}{ Antar varian bunga } \\
\hline - Var. Merah Kecil & 25,26 & 122,99 & 3790,33 & 498,67 & $635 \cdot 557,67$ \\
\hline - Var. Merah Besar & 22,55 & 55,65 & 1275,33 & 812,00 & $706.841,00$ \\
\hline - Var. Kuni ng Besar & 23,93 & 73,75 & 1771,00 & 339,33 & $319.136,00$ \\
\hline F stat. & 2,041 & 2,351 & 0,005 & 0,025 & 0,021 \\
\hline$P$ value & 0,155 & 0,119 & 0,995 & 0,974 & 0,978 \\
\hline
\end{tabular}

Dibanding kedua ras lahan lainnya, Petir juga menghasilkan bunga MK dan KB terbanyak (1,5 juta dan 780 ribu kuntum). Sementara itu, ras lahan Nglanggeran dan Bleberan memiliki ukuran populasi yang lebih kecil (141 dan 129 pohon berbunga dalam ras lahan). Karena itu, total bunga yang dihasilkan juga jauh lebih sedikit.

Umur dan ukuran tanaman merupakan penentu utama floral display (Herlihy \& Eckert 2005; Agullo et al. 2015). Kelimpahan bunga juga sangat dipengaruhi oleh faktor lingkungan seperti temperatur (Tamla et al. 2012; Ratnaningrum \& Indrioko 2014, 2015). Kelimpahan bunga pada ras lahan yang posisinya lebih tinggi, tampaknya juga berhubungan dengan temperatur lebih rendah, yang mengakibatkan lebih panjangnya periode anthesis (Sindhu-Vereendra \& Anantha-Padmanabha 1996; Tamla et al. 2012; Ratnaningrum \& Indrioko 2014). Perbedaan floral display antar varian dan populasi juga teramati pada jenis self-incompatible Aquilegia canadiensis disebabkan karakter lanskap yang berbeda. Dalam hal ini, populasi terisolasi cenderung memproduksi bunga lebih melimpah dan lebih besar, sebagai mekanisme alami untuk menjadi lebih self-compatible demi mempertahankan kelangsungan reproduksinya (Herlihy \& Eckert 2005). Jenis self-compatible Helianthemum caput-felis di lembah Mediterranean juga mengalami perbedaan pembungaan antara populasi di zona semi-arid dengan daerah yang lebih 
dingin. Populasi yang lebih dingin cenderung memproduksi lebih banyak bunga (Agullo et al. 2015).

Studi pada Phyteuma spicatum di Eropa Tengah menjumpai karakteristik pembungaan yang sama dengan cendana, yaitu bunga berukuran sangat kecil, hermafrodit, protandri, dan self-incompatible (Weber \& Kolb 2013). Tumbuhan Dianthus sylvestris di Italia bagian barat juga memiliki karakteristik pembungaan yang hampir sama dengan cendana, yaitu berukuran kecil, partially self compatible dan cenderung outcrossing (Collin \& Shykoff 2003). Pada kedua jenis ini, display pembungaan juga sangat dipengaruhi oleh umur, ukuran tanaman, ukuran populasi, dan lanskap. Umur dan ukuran tanaman mempengaruhi kemampuan tiap individu dalam memproduksi cabang, ranting, malai, dan bunga. Ukuran populasi berhubungan dengan jumlah individu yang mampu berbunga dalam populasi, dengan demikian berkorelasi positif dengan total produksi bunga dalam populasi. Sementara itu, pengaruh lanskap berhubungan dengan kemampuannya untuk menentukan ketersediaan faktor lingkungan yang dibutuhkan oleh tanaman untuk berbunga.

\section{Variasi Fenologi Pembungaan antar Varian dan Ras Lahan}

Ketika iklim berada dalam kondisi normal, frekuensi pembungaan cendana di Indonesia adalah dua kali dalam setahun: di awal musim kemarau pada bulan Mei-September, dan di awal musim penghujan pada bulan November-Maret; dengan durasi 4 hingga 5 bulan (Ratnaningrum \& Indrioko 2014, 2015). Pembungaan cendana di India pada umumnya juga terjadi dua kali dalam setahun, sepanjang FebruariJuni dan Agustus-Desember (Suma \& Balasundaran 2003), dan hal ini diduga merupakan respon terhadap datangnya musim panas pada bulan Februari atau berakhirnya musim panas di bulan Juni (SindhuVereendra \& Anantha-Padmanabha 1996).

Pada penelitian ini, seluruh ras lahan dan varian melangsungkan frekuensi pembungaan yang sama, yaitu dua kali dalam setahun. Namun, teramati perbedaan inisiasi dan durasi waktu pembungaan antar varian maupun ras lahan (Gambar 4). Varian KB selalu berbunga lebih awal di seluruh ras lahan, sedangkan varian MB adalah yang paling akhir. Durasi waktu pembungaan juga bervariasi antar varian maupun ras lahan. Varian MK memiliki longevity anthesis 1 hingga 2 minggu lebih panjang dibanding dua varian lainnya, sehingga durasi pembungaannya juga menjadi lebih panjang. Tidak pernah terjadi sinkroni (kesamaan waktu puncak pembungaan) antara varian KB yang berbunga paling awal dengan MB yang berbunga paling akhir. Sementara itu, dikarenakan longevity anthesisnya yang lebih panjang, varian MK memiliki peluang lebih besar untuk memperoleh sinkroni pembungaan, baik dengan varian KB maupun MB. Perlu penelitian lebih lanjut untuk mengetahui kemungkinan terjadinya perkawinan silang alami antar varian, terutama pada saat terjadi sinkroni pembungaan.

Ketinggian tempat, jenis dan kedalaman tanah, serta kondisi iklim, tampaknya berpengaruh terhadap perbedaan inisiasi dan durasi pembungaan antar ras lahan. Ras lahan yang lebih tinggi, lembab dan dingin, memulai pembungaannya paling lambat, dengan durasi yang juga lebih panjang. Nglanggeran, ras lahan yang paling tinggi (710 hingga $750 \mathrm{~m} \mathrm{dpl}$ ) dengan tipe iklim Am (rerata curah hujan $140 \mathrm{~mm}$, suhu udara $31,4^{\circ} \mathrm{C}$, kelembaban udara $72,5 \%$, dan status air tanah 20,9\%), memulai pembungaannya sekitar 4-6 minggu lebih lambat, dengan durasi 2-4 minggu lebih panjang. Petir berada pada ketinggian paling rendah (7o hingga $100 \mathrm{~m} \mathrm{dpl}$ ) dengan tipe iklim Aw yang kuat (rerata curah hujan 74,25 mm, suhu udara $39,3^{\circ} \mathrm{C}$, kelembaban udara $43,6 \%$, dan status air tanah 19,6\%). Pada ras lahan yang paling panas dan kering ini, inisiasi bunga selalu terjadi lebih awal, dengan durasi lebih singkat dibanding dua ras lahan lainnya. Bleberan terletak pada posisi lebih tinggi (150 hingga $170 \mathrm{~m} \mathrm{dpl}$ ) dengan tipe iklim intermediet antara Aw dan Am (rerata curah hujan 161,92 mm, suhu udara $34,7^{\circ} \mathrm{C}$, kelembaban udara $56,9 \%$, dan 
status air tanah 17,2\%). Pembungaan di ras lahan ini dimulai 1-2 minggu setelah Petir, dengan durasi yang juga 1-2 minggu lebih panjang.

Perubahan kondisi iklim dapat mempengaruhi fenologi pembungaan cendana dan membuatnya menyimpang dari pola yang seharusnya. Keguguran bunga dan buah secara massal terjadi pada dua ras lahan yang lebih rendah, sebagai respon dari kekeringan yang terjadi pada pertengahan musim hujan, bulan Februari hingga Maret 2015. Gugurnya bunga dan buah ini langsung diikuti oleh pembentukan kuncup-kuncup bunga baru, sehingga terjadi periode pembungaan baru, yang menyimpang dari waktu pembungaan yang seharusnya (biasa disebut sebagai sequential replacement; Dreyer et al. 2006), dengan durasi yang juga jauh lebih singkat. Fenomena sequential replacement ini terulang pada periode pembungaan di musim kemarau 2015. Periode ini mengalami kekeringan yang panjang dikarenakan tidak turunnya hujan pada bulan Juli hingga November 2015, terutama pada dua daerah yang lebih rendah. Hal ini mengakibatkan gugurnya bunga dan buah secara massal di kedua ras lahan tersebut. Turunnya hujan pertama pada bulan November 2015 di Bleberan, diikuti oleh Petir pada bulan Desember 2015, mengakibatkan terbentuknya kuncup-kuncup bunga baru di kedua ras lahan tersebut. Bagaimanapun, keguguran massal ini tidak terjadi pada ras lahan Nglanggeran yang terletak pada lokasi yang lebih tinggi dan tetap menerima hujan di musim kemarau, dan dengan demikian tidak terlalu terdampak oleh kekeringan dan perubahan iklim.

Pembungaan cendana sangat dipengaruhi oleh kondisi lingkungan seperti jenis dan kedalaman solum tanah (Warburton et al. 20oo; Lhuillier et al. 2006), ketinggian tempat (Vereendra \& Padmanabha 1996; Rao et al. 2007), serta parameter-parameter lingkungan yang dikondisikan oleh musim dan iklim, seperti temperatur dan kelembaban udara (Tamla et al. 2012; da Silva et al. 2016). Penelitian sepanjang tahun 2005 hingga 2010 (Ratnaningrum \& Indrioko
2014), yang dilanjutkan pada tahun 2013 hingga 2014 (Ratnaningrum \& Indrioko 2015), menjumpai bukti kuat bahwa pengaruh kondisi lingkungan terhadap pembungaan cendana terutama disebabkan oleh berbedanya status air tanah dan temperatur udara. Variasi pada kedua parameter lingkungan ini sangat dipengaruhi oleh curah hujan, ketinggian tempat, dan jenis tanah. Sebagaimana yang teramati pada penelitian ini, sejumlah penelitian terdahulu juga membuktikan bahwa cendana pada lokasi yang lebih tinggi, dengan lingkungan yang lebih lembab dan dingin, dan tanah yang mampu menyimpan lebih banyak air, akan berbunga lebih lambat dengan durasi lebih panjang. Cendana di lokasi lebih rendah, yang berhubungan dengan lingkungan yang panas, kering dan status air tanah yang rendah, selalu berbunga lebih awal dan lebih singkat. Di samping itu, pembungaan pada musim penghujan selalu terjadi lebih lambat dan panjang dibanding musim kemarau.

Pada zona iklim tropis dan arid, air merupakan faktor pembatas. Berbagai studi di daerah tropis dan arid mengindikasikan pengaruh musim terhadap pembungaan, disebabkan berubahnya curah hujan, temperatur (Alizoti et al. 2010) dan status air tanah (Dreyer et al. 2006; Lesica \& Kittelson 2010; Dalgleish et al. 2012; Haukka et al. 2013). Hal ini juga teramati pada jenis Oxals (Dreyer et al. 2006), apel, pir (Grab \& Craparo 2011) dan familia Gramineae (Dalgleish et al. 2012) di Afrika Selatan. Turunnya status air tanah mempercepat dan mempersingkat pembungaan dengan mempercepat proses fisiologis dalam bunga, seperti alokasi energi saat perkembangan kuncup, transpirasi bunga saat anthesis, serta akumulasi cadangan makanan saat perkembangan buah dan biji (Alizoti et al. 2010).

Perbedaan pada status air tanah, selain disebabkan oleh perbedaan curah hujan dan temperatur, juga dikarenakan berbedanya jenis tanah di tiap lokasi penelitian. Tiap jenis tanah memiliki kemampuan menahan air (water-holding capacities) yang berbeda (Haukka et al. 2013). Pada tanah yang 
berpasir, kehilangan air terjadi lebih cepat dibanding tanah lempung (Van Breemen \& Buurman 2002). Ras lahan Nglanggeran didominasi tanah latosol dengan kompleks bahan organik $\mathrm{Al}$ dan $\mathrm{Si}$, termasuk dalam grup tanah tua Andisol (Simanjuntak 2002). Pembentukan topsoil juga terjadi lebih intensif pada kondisi iklim yang dingin dan lembab. Agregat yang sangat porus pada Andisol meningkatkan kemampuan untuk menahan air dalam kapasitas yang besar, yang berakibat pada tingginya water retention dan water binding capacity. Kondisi ini memungkinkan tanah untuk mengumpulkan air sebanyak-banyaknya pada musim penghujan, dan mempertahankannya pada musim kemarau (Van Breemen \& Buurman 2002). Sementara itu, tanah di Bleberan didominasi oleh asosiasi mediteran merah dan grumosol hitam dengan batuan induk kapur, yang mengandung mineral lempung smektit dengan konsentrasi tinggi (Simanjuntak 2002). Kandungan lempung dan air yang terkonsentrasi pada daerah lembah atau dataran rendah menjadikan tingginya status air tanah pada areal tersebut; sedangkan areal yang lebih tinggi atau berbukit memiliki status air tanah yang rendah (Van Breemen \& Buurman 2002). Ras lahan Petir didominasi tanah yang mencirikan zona iklim kering, dengan akumulasi mineral terlarut seperti karbonat, sulfat dan klorit (Simanjuntak 2002). Tekanan osmotik yang tinggi karena tingginya konsentrasi garam berakibat pada rendahnya kemampuan menyimpan air, terutama pada musim kemarau (Van Breemen \& Buurman 2002)

Perubahan fenologi sepanjang gradien ketinggian tempat diduga kuat merupakan efek dari berbedanya temperatur pada ketinggian yang berbeda (Richardson et al. 2013). Tanaman yang secara alami tumbuh pada ketinggian yang rendah akan merespon kondisi panas dan kering secara lebih cepat, sebagaimana yang terjadi pada ras lahan Petir dan Bleberan dalam penelitian ini. Lebih lanjut, kebutuhan akan kondisi panas untuk pembungaan akan makin berkurang seiring dengan meningkatnya ketinggian tempat. Keterlambatan inisiasi bunga dan durasi panjang pembungaan, sebagaimana yang teramati pada ras lahan tertinggi dalam penelitian ini, juga teramati pada banyak tanaman semusim maupun menahun yang tumbuh di tempat yang lebih tinggi, pada kisaran geografis yang lebih luas (Lesica \& Kittelson 2010; Richardson et al. 2013).

Perubahan kondisi iklim dapat mempengaruhi fenologi pembungaan cendana dan membuatnya menyimpang dari pola yang seharusnya. Keguguran bunga dan buah secara massal, yang teramati sebagai efek dari dua kali kekeringan pada pertengahan musim hujan dan akhir kemarau 2015, juga pernah teramati pada penelitian-penelitian sebelumnya. Kekeringan mengubah frekuensi pembungaan cendana menjadi tiga kali setahun dengan durasi yang jauh lebih singkat pada tahun 2007 (Ratnaningrum \& Indrioko 2014), (Ratnaningrum \& Indrioko 2015) dan 2015 (penelitian ini). Fenomena serupa teramati pada tanaman apel, pir (Grab \& Craparo 2011) dan Oxalis (Dreyer et al. 2006) di Afrika Selatan, yang mengalami keguguran bunga dan sequential replacement yang merubah frekuensi pembungaannya, dikarenakan kekeringan panjang yang menurunkan status air tanah. Ketika kondisi lingkungan kembali normal, biasanya tanaman akan kembali ke pola pembungaan semula (flowering plasticity; Lesica \& Kittelson 2010); hal yang juga teramati pada penelitian ini. Hal ini merupakan kemampuan adaptasi alami dari tanaman, terutama yang tumbuh pada kondisi lingkungan yang ekstrim, seperti daerah arid dan semi-arid (Lesica \& Kittelson 2010).

Perbedaan fenologi pembungaan antar varian bunga mengindikasikan adanya kendali faktor genetik pada pembungaan cendana. Hal ini juga teramati pada penelitian terdahulu terhadap beberapa provenan cendana dari Pulau Timor dan Jawa yang ditanam bersama di areal konservasi ex situ Wanagama, Gunungkidul (Ratnaningrum \& Indrioko 2014). Bahkan setelah ditanam pada kondisi lingkungan yang berbeda, seluruh provenan dari Timor tetap mempertahankan pola pembungaan 

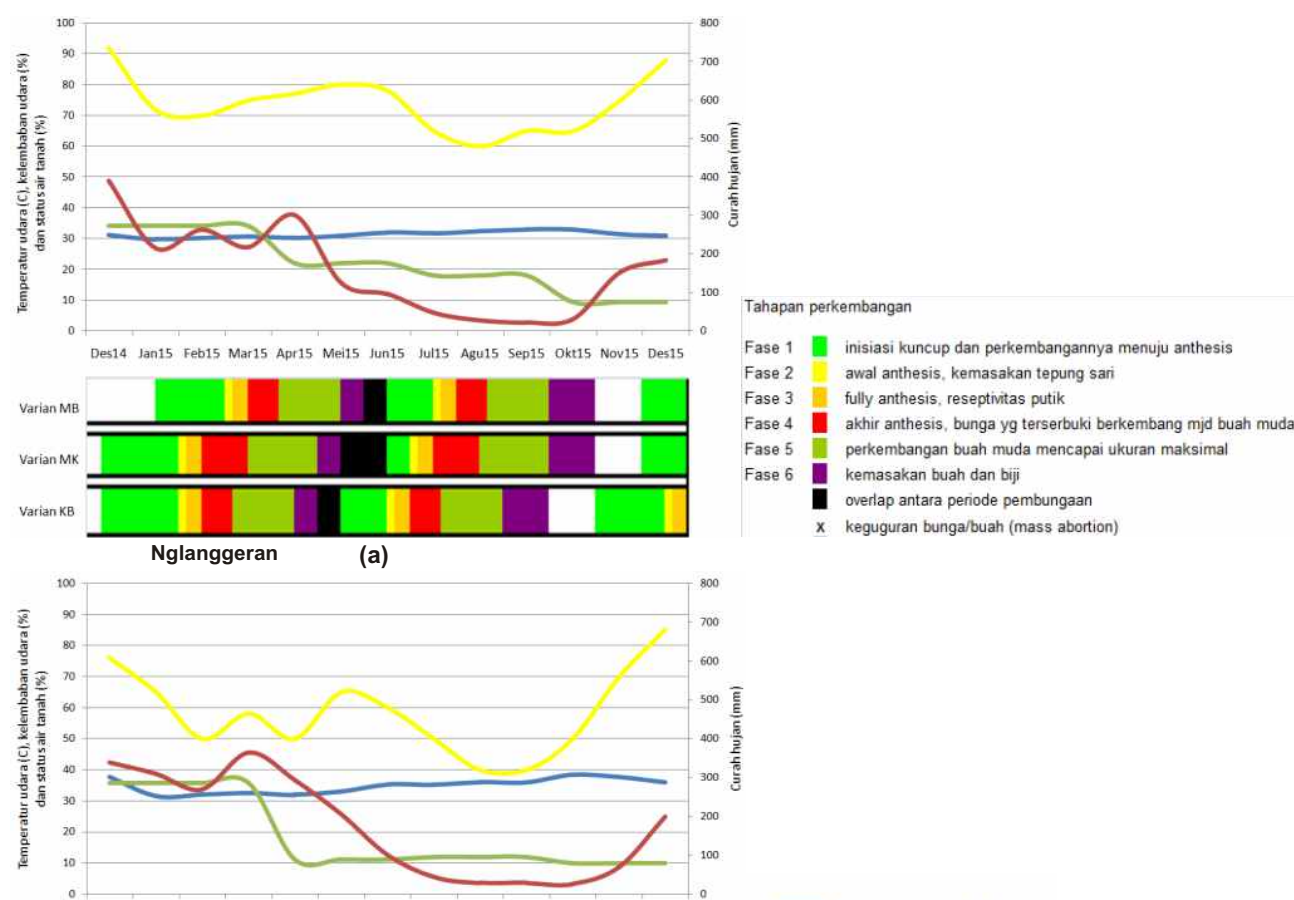

Des14 Jan15 feb15 Mar15 Apr15 Mei15 Jun15 Jul15 Agu15 Sep15 Okn15 Nov15 Des15

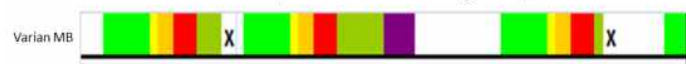

- Status air tanah $(\%)$

Kelembaban udara (\%)

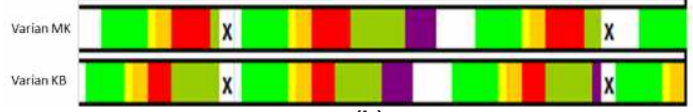

Curah hujan (mm)

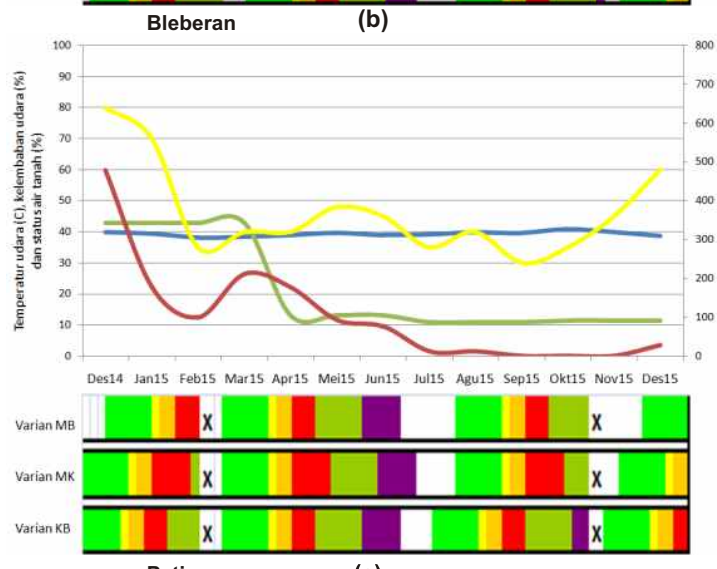

Petir

(c)

Gambar 4. Fenologi pembungaan tiga varian cendana pada tiga ras lahan di Gunung Sewu: Nglanggeran (a), Bleberan (b) dan Petir (c) pada periode pembungaan tahun 2015. Ordinaty primer menunjukkan rerata temperatur udara $\left({ }^{\circ} \mathrm{C}\right)$, status air tanah (\%) dan kelembaban udara (\%), yang masing-masing direpresentasikan dengan garis biru, hijau dan kuning. Ordinat y sekunder menunjukkan rerata curah hujan $(\mathrm{mm})$ yang digambarkan dengan garis merah. Absis horizontal $\mathrm{x}$ menunjukkan bulan dalam tahun 2015. Fenologi pembungaan terbagi menjadi enam tahapan perkembangan bunga dari kuncup hingga buah masak, yang dilambangkan dengan warna-warna yang berbeda. Tanda X menunjukkan keguguran bunga dan/atau buah secara massal.

Figure 4. Flowering phenology of three sandalwood variants grown at three landraces in Gunung Sewu: Nglanggeran (a), Bleberan (b) and Petir (c) in 2015 flowering periods. The primary yordinate indicates monthly temperature $\left({ }^{\circ} \mathrm{C}\right)$, soil moisture (\%) and the relative humidity (\%), each represented by blue, green and yellow lines, respectively. The secondaryy ordinate indicates the monthly rainfall $(\mathrm{mm})$ represented by red line. The horizontal $x$ line represented the months during the year 2015. Flowering phenology derived into six developmental phases that is marked by different colors. The X marks showed the mass flowers or fruits abortion.

sebagaimana yang dilangsungkan di daerah asalnya. Provenan Timor berbunga lebih awal dan singkat dibanding ras lahan dari Jawa. Perbedaan struktur dan fenologi pembungaan antar varian juga teramati pada cendana di India (Sindhu-Vereendra \& AnanthaPadmanabha 1996; Rao et al. 2007) dan Australia (Tamla et al. 2012), dan seluruh penelitian tersebut menggarisbawahi kendali genetik sebagai penyebab 
utama perbedaan pembungaan ini. Faktor genetik ini mengendalikan pembungaan cendana dengan menentukan ekspresi dan respon gen-gen pembungaan terhadap stimulan dari faktor lingkungan (da Silva et al. 2016). Cendana dengan genotip yang sama juga cenderung memiliki karakter pembungaan yang sama, terutama dalam hal struktur bunga dan kemasakan organ reproduksi (Ratnaningrum dan Indrioko, 2014).

Sejumlah penelitian pada Ficus microcarpa (Yang et al. 2013), Kolkwitzia amabilis (Park et al. 2014), dan Pinus nigra (Alizoti et al. 2010), juga membuktikan bahwa genotip yang berbeda akan menampilkan respon pembungaan yang berbeda, walaupun ditanam pada kondisi lingkungan yang sama. Namun, dibutuhkan studi genetika yang lebih detil untuk dapat membuktikan hal ini.

\section{Implikasi pada Konservasi Genetik}

Pembungaan merupakan salah satu komponen penting dalam konservasi genetik dikarenakan pengaruhnya terhadap sistem perkawinan, potensi reproduksi, dan struktur genetik dalam populasi. Variasi lanskap seperti ketinggian tempat, topografi, dan jenis tanah menentukan faktor-faktor lingkungan yang dapat diterima oleh populasi, misalnya temperatur, kelembaban dan status air tanah, dan karenanya juga sangat mempengaruhi berjalannya proses genetik dan reproduksi. Penelitian ini merupakan langkah sangat awal untuk mendeteksi adanya variasi karakter pembungaan yang disebabkan oleh berbedanya varian bunga dan struktur lanskap di Gunung Sewu. Hasil penelitian ini diharapkan dapat berkontribusi dalam penyusunan strategi konservasi cendana, terutama yang berbasis maksimalisasi penyerbukan alam dan terkendali pada tingkat intramaupun inter-varian.

Perbedaan struktur dan longevity organ reproduksi dijumpai antar varian bunga. Perbedaan antar varian ini membawa konsekuensi berbedanya jenis dan intensitas kunjungan agen penyerbuk, yang dapat berdampak pada berbedanya produksi biji. Dibutuhkan penelitian lebih lanjut untuk mengetahui preferensi agen penyerbuk terhadap masing-masing varian bunga, dampaknya terhadap tingkat perkawinan sendiri dan silang, serta keberhasilan produksi bijinya. Untuk selanjutnya, upaya konservasi berbasis manajemen penyerbukan dan agen penyerbuk perlu difokuskan pada peningkatan perkawinan silang di dalam masing-masing varian, dengan tetap mempertimbangkan kemungkinan persilangan antar varian.

Perbedaan struktur dan longevity organ reproduksi antar varian teramati konsisten di setiap ras lahan. Hal ini mengindikasikan adanya kendali genetik, dan oleh karena itu, dibutuhkan studi genetika untuk mengetahui diferensiasi genetis setiap varian. Perlu dipertimbangkan kemungkinan revisi taksonomi berbasis penanda biokimia maupun molekuler. Jika susunan genetisnya memang terbukti berbeda, maka ketiga varian ini perlu dikelola dalam unit konservasi yang juga terpisah.

Di samping itu, perbedaan struktur dan longevity organ reproduksi juga mengakibatkan sulitnya ketiga varian ini untuk dapat berkawin silang di alam. Varian MK yang paling berbeda struktur reproduksi dan longevity-nya, mengindikasikan adanya mekanisme hambatan perkawinan (mating barriers), yang memperbesar hambatan untuk berkawin silang dengan kedua varian lainnya. Sementara itu, varian MB dan KB memiliki kesamaan struktur dan longevity organ reproduksi, sehingga masih dimungkinkan untuk berkawin silang. Sehubungan dengan hal itu, selain studi genetika, dibutuhkan penelitian lebih lanjut untuk mengetahui crossability masing-masing varian dalam persilangan inter- dan intraspesifik. Merujuk kepada definisi lungkang gen (gene pool), maka suatu varian dapat dikategorikan dalam lungkang gen yang sama jika mampu melangsungkan perkawinan silang secara alami. Hasil dari studi crossability akan menjadi acuan dalam pengelompokan masing-masing varian ke dalam lungkang gennya. 
Varian yang dapat berkawin silang akan dikelompokkan dalam lungkang gen yang sama, sedangkan yang mengalami inkompatibilitas persilangan akan dipisahkan dalam lungkang gen yang berbeda.

Perbedaan inisiasi dan durasi pembungaan menjadikan asinkroni pembungaan antar varian bunga. Tidak pernah terjadi sinkroni pembungaan antara varian KB yang berbunga paling awal dengan MB yang berbunga paling akhir. Sementara itu, varian MK yang durasi pembungaannya lebih panjang, memiliki peluang lebih besar untuk memperoleh sinkroni pembungaan, baik dengan varian KB maupun MB. Perlu penelitian lebih lanjut untuk mengetahui kemungkinan terjadinya perkawinan silang alami antar varian, beserta resiko-resiko yang menyertainya, misalnya hambatan perkawinan (mating barriers) dan outbreeding depression. Jika ternyata ketiga varian ini dapat berkawin silang secara bebas di alam, dan jika tidak terjadi outbreeding depression, maka sinkroni pembungaan ini akan menguntungkan disebabkan terjadinya peningkatan perkawinan silang antar varian. Dengan demikian, ketiga varian dapat dikelola bersama-sama dalam satu unit konservasi untuk memaksimalkan perkawinan silang. Namun, jika ternyata terjadi hambatan perkawinan antar varian, perkawinan silang akan mengakibatkan outbreeding depression, dan oleh karena itu ketiga varian harus dikelola secara terpisah.

Pengelolaan masing-masing varian dalam unit konservasi yang terpisah juga harus mempertimbangkan basis genetik dan ukuran populasi efektif. Penelitian terdahulu membuktikan bahwa populasi yang memiliki banyak induk berbunga (ukuran populasi efektif besar), dengan basis genetik yang luas, cenderung mampu melangsungkan perkawinan silang interspesifik secara alami dan mempertahankan diversitas genetiknya. Karena itu, perlu dipastikan bahwa varian yang sama dalam satu unit konservasi tidak tersusun atas individu yang berkerabat, untuk meminimalisir kemungkinan terjadinya perkawinan sendiri. Stimulasi pembungaan pada genotip-genotip yang berbeda dapat dijadikan pertimbangan untuk meningkatkan ukuran populasi efektif dan perkawinan silang.

Perbedaan pembungaan antar varian bunga diduga lebih dipengaruhi oleh kendali genetik. Sementara itu, perbedaan antar ras lahan tampaknya lebih merupakan pengaruh dari faktor lingkungan seperti ketinggian tempat, jenis dan kedalaman tanah, serta iklim. Ras lahan yang lebih rendah, dengan lingkungan yang lebih kering dan panas, berbunga lebih awal dan singkat. Pembungaan di tiap ras lahan juga sangat sensitif terhadap perubahan iklim. Peningkatan temperatur ekstrim, yang berdampak pada turunnya status air tanah, berdampak pada keguguran massal bunga dan buah, yang diikuti oleh sequential replacement atau terbentuknya periode pembungaan baru. Hal ini berakibat pada berubahnya frekuensi pembungaan, terutama ketika terjadi musim kemarau yang panjang atau kekeringan di tengah musim hujan. Sehubungan dengan itu, maka ketinggian tempat, jenis dan kedalaman tanah, serta kondisi iklim yang mengakibatkan perbedaan pembungaan antar ras lahan, juga perlu menjadi pertimbangan dalam manajemen pembungaan dan konservasi genetik cendana.

\section{Kesimpulan}

Struktur pembungaan, ciri kemasakan serta longevity organ reproduksi berbeda antar varian bunga. Namun dalam varian yang sama, tidak dijumpai perbedaan struktur, ciri kemasakan serta longevity organ reproduksi antar ras lahan. Komponen display pembungaan bervariasi antar ras lahan dikarenakan bervariasinya umur dan jumlah pohon berbunga. Seluruh ras lahan dan varian melangsungkan frekuensi pembungaan yang sama, yaitu dua kali dalam setahun. Namun, dijumpai perbedaan inisiasi dan durasi pembungaan. Perbedaan antar ras lahan lebih merupakan pengaruh dari faktor lingkungan seperti ketinggian tempat, jenis dan kedalaman tanah, serta iklim. Pembungaan 
di tiap ras lahan juga sangat sensitif terhadap perubahan iklim.

Ketinggian tempat, jenis dan kedalaman tanah, serta kondisi iklim yang mengakibatkan perbedaan pembungaan antar ras lahan, perlu menjadi pertimbangan dalam manajemen pembungaan dan konservasi genetik cendana. Sementara itu, karena perbedaan pembungaan antar varian diduga merupakan kendali genetis, maka dibutuhkan studi genetika untuk mengetahui diferensiasi genetis setiap varian, serta studi crossability untuk mengetahui kompatibiltas masing-masing varian dalam persilangan inter- dan intraspesifik. Jika susunan genetis dan crossability ketiganya memang terbukti berbeda, maka ketiga varian ini kemungkinan berada dalam susunan taksonomi yang berbeda, perlu diklasifikasikan dalam lungkang gen (gene pool) yang berbeda, dan dikelola dalam unit konservasi yang juga terpisah. Pengelolaan masing-masing varian dalam unit konservasi yang terpisah juga harus mempertimbangkan basis genetik dan ukuran populasi efektif. Lebih lanjut, dibutuhkan pula penelitian untuk mengetahui preferensi agen penyerbuk terhadap masing-masing varian bunga, dampaknya terhadap tingkat perkawinan sendiri dan silang, serta keberhasilan produksi bijinya. Strategi konservasi pada cendana di Gunung Sewu perlu dirancang berbasis keragaman genetik, varian bunga, dan kompatibilitas antar varian, dengan tetap mempertimbangkan keberagaman tempat tumbuhnya.

\section{Daftar Pustaka}

Agullo JC, Perez-Banon C, Crespo MB, Juan A. 2015. Puzzling out the reproductive biology of the cat's head rockrose (Helianthemum caput-felis, Cistaceae). Flora 217: 75-81.

Alizoti PG, Kilimis K, Gallios P. 2010. Temporal and spatial variation of flowering among Pinus nigra Arn. clones under changing climatic conditions. Forest Ecology and Management 259:786-797.

Angadi VG, Jain SH, Shankaranarayana KH. 2003. Genetic diversity between sandal populations of different provenances in India. Institute of Wood Science and Technology. Bangalore, India.

Anonim. 2015. Program rehabilitasi cendana di NTT telah gagal. Harian Kompas online. http://www.kompas.com. Diakses April 2015.
Arroyo MTK, Munoz MS, Henríquez C, Till-Bottraud I, Perez F. 2006. Erratic pollination, high selfing levels and their correlates and consequences in an altitudinally widespread above-tree-line species in the high Andes of Chile. Acta Oecologica 30: 248-257.

Barrett SCH, Baker AM, Jesson LK. 2006. Mating strategies in Monocotyledons. Monocots Newsletter II. Department of Botany, University of Toronto. Ontario, Canada.

Bottin L, Tassin J, Nasi R, Bouvet JM. 2007. Molecular, quantitative and abiotic variables for the delineation of evolutionary significant units: case of sandalwood (Santalum austrocaledonicum Vieillard) in New Caledonia. Conservation Genetics 8:99-109

Brand JE. 1994. Genotypic variation in Santalum album. Sandalwood Research Newsletter. II-1994.

Byrne M, MacDonald B, Broadhurst L, Brand J. 2003. Genetic differentiation in Western Australian sandalwood (Santalum spicatum) as revealed by nuclear RFLP. Theoritical and Applied Genetics 107:1208-1214

Collin CL, Shykoff JA. 2003. Outcrossing rates in the gynomonoecious-gynodioecious species Dianthus sylvestris (Caryophyllaceae). American Journal of Botany 9o(4): 579-585.

da Silva JAT, Page T, Zhang X, Kher MM, Nataraj M, Soner D, Ma G. 2016. Sandalwood: basic biology, tissue culture, and genetic transformation. Planta 243: 847-887

Dalgleish HJ, Ott JP, Setshogo MP, Hartnett DC. 2012. Inter-specific variation in bud banks and flowering effort among semi-arid African savanna grasses. South African Journal of Botany 83: 127-133.

Dani KGS, Ravikumar P, Kumar RP, Kush A. 2011. Genetic variation within and among small isolated populations of Santalum album. Biologia Plantarum 55 (2): 323-326

Dinas Kehutanan DIY. 2015. Laporan inventory tegakan hutan di Kabupaten Gunungkidul. Bagian Perencanaan dan Pemetaan Hutan. KPHP Dinas Kehutanan Daerah Istimewa Yogyakarta.

Dreyer LL, Esler KJ, Zietsman J. 2006. Flowering phenology of South African Oxalis-possible indicator of climate change? South African Journal of Botany 72: 150 - 156.

Fernandez VA, Galetto L, Astegiano J. 2009. Infuence of flower functionality and pollination system on the pollen size-pistil length relationship. Organisms, Diversity, \& Evolution $9: 75^{-82}$.

Ghazoul J. 1997. Field studies of forest tree reproductive ecology. ASEAN-Canada Forest Tree Seed Center Project, Saraburi, Thailand.

Grab S, Craparo A. 2011. Advance of apple and pear full bloom dates in response to climate change in the south-western Cape, South Africa: 1973-2009. Agricultural \& Forest Meteorology 151: 406-413.

Harbaugh DT, Baldwin BG. 2007. Phylogeny and biogeography of the Sandalwoods (Santalum, Santalaceae): repeated dispersals throughout the Pacific. American Journalof Botany 94(6): 1028-1040.

Haryono E, Suratman. 2010. Significant features of Gunung Sewu Karst as geopark site. Proceeding on $4^{\text {th }}$ International UNESCO Conference on Geopark. April 12-15, 2010, Langkawi.

Haukka AK, Dreyer LL, Esler KJ. 2013. Effect of soil type and climatic conditions on the growth and flowering 
phenology of three Oxalis species in the Western Cape, South Africa. South African Journal of Botany 88: 152-163.

Herawan T, Na'iem M, Indrioko S, \& Indrianto A. 2014. Somatic embryogenesis of Sandalwood (Santalum album L.). Indonesian Journal of Biotechnology 19(2):168-175.

Herlihy CR, Eckert CG. 2005. Evolution of self-fertilization at geographical range margins? A comparison of demographic, floral, and mating system variables in central vs. peripheral populations of Aquilegia canadensis (Ranunculaceae). American Journal of Botany 92(4): 744-751.

Indrioko S, Ratnaningrum YWN. 2016. Genetic differentiation, mating systems and crossability of three floral variants of sandalwood in Gunung Sewu Geopark. Prosiding $1^{\text {st }}$ International Conference on Tropical Agriculture (ICTA) 2016. November 2016, Yogyakarta.

Indrioko S, Ratnaningrum YWN. 2015. Habitat loss caused clonality, genetic diversity reduction and reproductive failure in Santalum album (Santalaceae), an endangered endemic species of Indonesia. Hlm. 658-664. Procedia Environmental Sciences V.

IUCN. 2009. IUCN Red List Categories And Criteria: Version 3.1. International Union for Conservation of Nature and Natural Resources. Glad, Switzerland, and Cambridge. UK.

Jones CE, Little RJ. 1983. Handbook of experimental pollination biology. Van Nostrand Reinhold Co. Inc. New York.

Lesica P, Kittelson PM. 2010. Precipitation and temperature are associated with advanced flowering phenology in a semi-arid grassland. Journal of Arid Environments 74: 1013-1017.

Lhuillier E, Butaud JF, Bouvet JM. 20o6. Extensive clonality and differentiation in the insular Pacific tree Santalum insulare: implications to its conservation. Annals of Botany 98: 1061-1072.

Owens JN, Sornsathapornkul P, Thangmitcharoen S. 2001. Studying flowering and seed ontogeny in tropical forest trees. ASEAN-Canada Forest Tree Seed Centre. Muak-lek, Saraburi 1818o.

Park SH, Burchi G, Roh MS, Joung YH. 2014. Characterization of Kolkwitzia amabilis accessions based on flowering and molecular markers. Scientia Horticulturae 165: 190-195

Rao MN, Ganeshaiah KN, Shaanker RU. 2007. Assessing threats and mapping sandal resources to identify genetic 'hot-spot' for in-situ conservation in peninsular India. Conservation Genetics 8:925-935.

Ratnaningrum YWN, Indrioko S, Faridah E, Syahbudin A. 2016. Flowering and seed production of sandalwood (Santalum album Linn., Santalaceae) along environmental gradients in Gunung Sewu Geopark, Indonesia. Nusantara Bioscience 8(2): 180-191.

Ratnaningrum YWN, Indrioko S. 2016. Differences on floral structure of sandalwood along landscape gradients in Gunung Sewu and its consequences on pollination and reproductive outputs. Prosiding $1^{\text {st }}$ International Conference on Tropical Agriculture (ICTA). November, 2016, Yogyakarta.

Ratnaningrum YWN, Indrioko S. 2015. Response of flowering and seed production of sandalwood (Santalum album Linn) to climate changes. Hlm. 665-675. Procedia Environmental Sciences V.

Ratnaningrum YWN, Indrioko S. 2014. Variation on genotypes and flowering characters affecting pollination mechanisms of sandalwood (Santalum album Linn., Santalaceae) planted on ex-situ gene conservation in Yogyakarta, Indonesia. Eurasian Journal of Forest Research 6: 167-179.

Ratnaningrum YWN, Prehaten D. 2005. Pollination mechanisms and breeding systems of Santalum album (Santalaceae), the endemic species of Eastern parts of Indonesia that became landrace of Gunungkidul, Central Java. Proceeding on The International Forestry Seminar. Faculty of Food and Agriculture. Universiti Putra Malaysia. March 7-9, 2005, Serawak, Malaysia.

Richardson AD, Keenan TF, Migliavacca M, Ryua Y, Sonnentaga O \& Toomey M. 2013. Climate change, phenology, and phenological control of vegetation feedbacks to the climate system. Agricultural and Forest Meteorology 169: 156- 173 .

Rughkla A, McComb JA, Jones MGK. 2006. Intra-and inter specific pollination of Santalum spicatum and S. album. Australian Journal of Botany 45(6): 1083-1095.

Simanjuntak T. 2002. Gunung Sewu in prehistoric times. Gadjah Mada University Press. Yogyakarta.

Sindhu-Veerendra HC, Anantha-Padmanabha HS. 1996. The breeding system in Sandal (Santalum album L.). Silvae Genetica 45(4): 188-190.

Suma TB, Balasundaran M. 2003. Isozyme variation in five provenances of Santalum album in India. Australian Journal of Botany 51(3): 243-249.

Tamla HT, Cornelius JP, Page T. 2012. Reproductive biology of three commercially valuable Santalum species: development of flowers and inflorescences, breeding systems, and interspecific crossability. Euphytica 184:323-333.

Tsaliki M, Diekmann M. 2011. Population size, pollination and reproductive success in two endangered Genista species. Flora 206: 246-250.

Van-Breemen N, Buurman P. 2002. Soil formation. Kluwer Academic Publishers, Doordrecht.

Warburton CL, James EA, Fripp YJ, Trueman SJ, Wallace HM. 200o. Clonality and sexual reproductive failure in remnant populations of Santalum lanceolatum (Santalaceae). Biological Conservation. 96(1):45-54.

Weber A, Kolb A. 2013. Population size, pollination and phenotypic trait selection in Phyteuma spicatum. Acta Oecologica 47:46-51.

White TL, Adams WT, Neale DB. 2007. Forest genetics. CABI Publishing. $\mathrm{CAB}$ International. Wallingford, Oxfordshire, UK.

Wolf PG, Campbell DR, Waser NM, Sipes SD, Toler TR, Archibald JK. 2001. Tests of pre- and postpollination barriers to hybridization between sympatric species of Ipomopsis (Polemoniaceae). American Journal of Botany 88(2): 213-219.

Yang HW, Bain A, Garcia M, Chou LS, Kjellberg F. 2013. Evidence of genetic influence on the flowering pattern of Ficus microcarpa. Acta Oecologica 30: 1-7. 